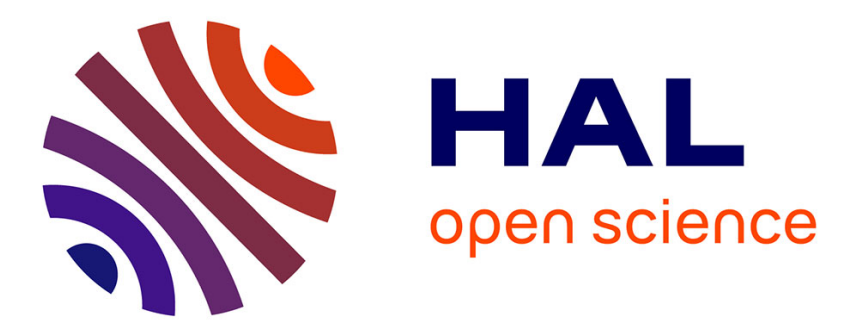

\title{
Plutonium isotopes as tracers for ocean processes: A review
}

Patric Lindahl, Sang-Han Lee, Paul J. Worsfold, Miranda Keith-Roach

\section{To cite this version:}

Patric Lindahl, Sang-Han Lee, Paul J. Worsfold, Miranda Keith-Roach. Plutonium isotopes as tracers for ocean processes: A review. Marine Environmental Research, 2010, 69 (2), pp.73. 10.1016/j.marenvres.2009.08.002 . hal-00563095

\section{HAL Id: hal-00563095 \\ https://hal.science/hal-00563095}

Submitted on 4 Feb 2011

HAL is a multi-disciplinary open access archive for the deposit and dissemination of scientific research documents, whether they are published or not. The documents may come from teaching and research institutions in France or abroad, or from public or private research centers.
L'archive ouverte pluridisciplinaire HAL, est destinée au dépôt et à la diffusion de documents scientifiques de niveau recherche, publiés ou non, émanant des établissements d'enseignement et de recherche français ou étrangers, des laboratoires publics ou privés. 


\section{Accepted Manuscript}

Plutonium isotopes as tracers for ocean processes: A review

Patric Lindahl, Sang-Han Lee, Paul Worsfold, Miranda Keith-Roach

PII:

S0141-1136(09)00107-X

DOI:

10.1016/j.marenvres.2009.08.002

Reference:

MERE 3364

To appear in:

Marine Environmental Research

Received Date:

25 May 2009

Revised Date:

17 August 2009

Accepted Date:

18 August 2009

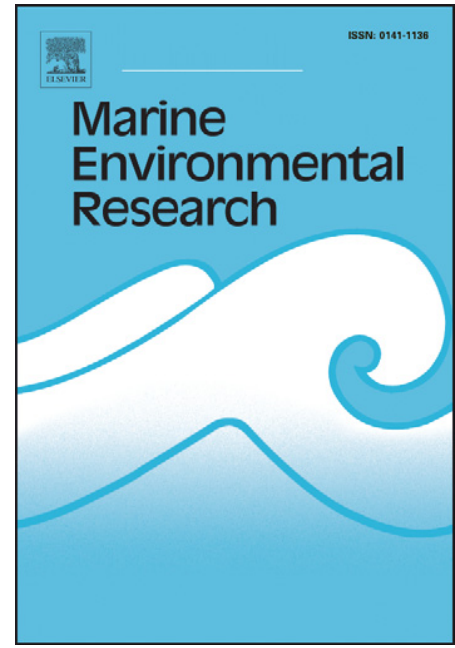

Please cite this article as: Lindahl, P., Lee, S-H., Worsfold, P., Keith-Roach, M., Plutonium isotopes as tracers for ocean processes: A review, Marine Environmental Research (2009), doi: 10.1016/j.marenvres.2009.08.002

This is a PDF file of an unedited manuscript that has been accepted for publication. As a service to our customers we are providing this early version of the manuscript. The manuscript will undergo copyediting, typesetting, and review of the resulting proof before it is published in its final form. Please note that during the production process errors may be discovered which could affect the content, and all legal disclaimers that apply to the journal pertain. 


\author{
Patric Lindahl ${ }^{1,3^{*}}$, Sang-Han Lee ${ }^{2}$, Paul Worsfold ${ }^{3}$ and Miranda Keith-Roach ${ }^{3}$ \\ ${ }^{1}$ Marine Environment Research Department, Korea Ocean Research \& Development Institute, Ansan P.O. Box \\ 29, Seoul 425-600, Republic of Korea \\ ${ }^{2}$ Division of Metrology for Quality Life, Korea Research Institute of Standards and Science, 1 Doryong-Dong, \\ Yuseong-Gu, Daejeon 305-340, Republic of Korea \\ ${ }^{3}$ School of Earth, Ocean and Environmental Sciences, University of Plymouth, Drake Circus, Plymouth PL48AA, \\ $U K$
}

\title{
Abstract
}

Since the first nuclear weapons tests in the 1940s, pulsed inputs of plutonium isotopes have served as excellent tracers for understanding sources, pathways, dynamics and the fate of pollutants and particles in the marine environment. Due to the well-defined spatial and temporal inputs of $\mathrm{Pu}$, the long halflives of ${ }^{240} \mathrm{Pu}$ and ${ }^{239} \mathrm{Pu}$ and its unique chemical properties, $\mathrm{Pu}$ is a potential tracer for various physical and biogeochemical ocean processes, including circulation, sedimentation and biological productivity, and hence a means of assessing the impacts of global climate change. Due to the source dependency of the $\mathrm{Pu}$ isotopic signature, plutonium isotopes are beginning to be exploited as tools for the evaluation and improvement of regional and global ocean models that will enhance understanding of past and future changes in the oceans. This paper addresses the major sources of $\mathrm{Pu}$ and the physical and biogeochemical behaviour in the marine environment. Finally, the use of Pu isotopes as tracers for various oceanic processes (e.g. water mass transport, particle export, and sedimentation) is considered.

Keywords: plutonium; isotopic ratio; inventory; source term, marine environment; marine tracer; water; sediment; biota

\footnotetext{
* Corresponding author: Tel.: +82 103908 7108; Fax: +82 314084493

E-mail address: patriclindahl@yahoo.com (P. Lindahl)
} 


\section{Introduction}

The World Ocean plays a critical role in regulating the earth's climate and reliable tracers are required to predict water mass movement and elucidate ocean processes. Anthropogenic radionuclides play important roles as tracers for ocean processes (Dahlgaard, 1995; Livingston and Povinec, 2002) and can be used to reconstruct past environmental conditions and therefore enhance our knowledge about past and future climate change. In addition, the distribution of anthropogenic radionuclides can be modelled to derive rates of ocean transport on timescales not attainable by direct measurement. Since the input histories of anthropogenic radionuclides to the environment are well known, it enables us to trace small-scale (near shore) and large-scale oceanic processes (circulation, sedimentation and biological productivity) and predict future climate change processes and their impact on the marine environment.

Plutonium has been released into the marine environment since the first nuclear weapons test in 1945. Plutonium isotopes are mainly produced by neutron irradiation of uranium, and the isotopic composition of $\mathrm{Pu}$ is characteristic of the source, as it depends on the neutron intensity and the duration of irradiation. Plutonium concentrations in the marine environment are continuously changing due to marine processes such as ocean currents, sedimentation, remobilisation and biological uptake. The well-defined spatial and temporal source terms and high particle affinity of Pu provide a powerful tool for studying a variety of processes in the marine environment such as water mass transport (advection and convection), particle fluxes and scavenging, and validating various global circulation and biogeochemical ocean models. The most frequently studied $\mathrm{Pu}$ isotopes in the marine environment are ${ }^{238} \mathrm{Pu}$ $\left(\mathrm{T}_{1 / 2}=87.74 \mathrm{a}\right),{ }^{239} \mathrm{Pu}\left(\mathrm{T}_{1 / 2}=24100 \mathrm{a}\right),{ }^{240} \mathrm{Pu}\left(\mathrm{T}_{1 / 2}=6561 \mathrm{a}\right),{ }^{241} \mathrm{Pu}\left(\mathrm{T}_{1 / 2}=14.33 \mathrm{a}\right)$ and ${ }^{242} \mathrm{Pu}\left(\mathrm{T}_{1 / 2}\right.$ $=373000$ a) with ${ }^{239} \mathrm{Pu}$ and ${ }^{240} \mathrm{Pu}$ as the most abundant in the marine environment.

Recent advances in analytical procedures and Inductively Coupled Plasma Mass 
Spectrometry (ICP-MS) have improved the determination of low concentrations of $\mathrm{Pu}$ and provide precise isotopic ratios with reasonable costs (Kim et al., 2007; Ketterer and Szechenyi, 2008; Qiao et al., 2009). Previously, Pu analysis in marine samples was mainly performed by conventional alpha spectrometry, with the disadvantage of long measurement times and no resolution between ${ }^{239} \mathrm{Pu}$ and ${ }^{240} \mathrm{Pu}$, due to similar alpha energies.

Comprehensive studies on the distribution and behaviour of $\mathrm{Pu}$ in the marine environment have been summarised in several review papers (e.g. Sholkovitz, 1983; Baxter et al., 1995; Livingston and Povinec, 2000; Livingston et al., 2001; Livingston and Povinec, 2002; Hamilton, 2005; León Vintró et al., 2005).

The specific aim of this paper is to provide an overview of the use of $\mathrm{Pu}$ isotopes as tracers for various processes in the marine environment. First, the major Pu sources to the marine environment and their isotopic composition are summarised. This is followed by an overview of the geochemical and biogeochemical processes affecting the behaviour and distribution of $\mathrm{Pu}$ isotopes in the marine environment. Finally, the utility of $\mathrm{Pu}$ isotopes as tracers for various marine processes is considered, with an emphasis on the use of specific $\mathrm{Pu}$ isotopic composition (e.g. ${ }^{240} \mathrm{Pu} /{ }^{239} \mathrm{Pu}$ ratio).

\section{Sources of $\mathrm{Pu}$ in the oceans}

The majority of $\mathrm{Pu}$ in the environment is derived from man-made sources with only trace amounts from natural sources (Taylor, 2001). The main sources of Pu isotopes in the World Ocean are fallout from atmospheric nuclear weapons testing and liquid discharges from nuclear reprocessing plants (León Vintró et al., 2005). Other sources that have impacted on Pu levels in the marine environment at the local and/or regional scale are the Chernobyl accident, aircraft accidents involving nuclear weapons, burn-up of nuclear powered satellites and, to a 
lesser extent, dumping of radioactive wastes and the loss of nuclear submarines. The composition of $\mathrm{Pu}$ isotopes from different sources in the marine environment varies significantly due to the characteristic isotopic composition corresponding to the means of production (see Table 1). Reactor-grade Pu typically contains more than $35 \%{ }^{239} \mathrm{Pu}$ with a ${ }^{240} \mathrm{Pu} /{ }^{239} \mathrm{Pu}$ atom ratio of $0.2-1.0$ after fuel burn-up (Yamana et al., 2001). The ${ }^{240} \mathrm{Pu} /{ }^{239} \mathrm{Pu}$ atom ratio in weapon-grade $\mathrm{Pu}$ is much lower $(0.02-0.06)$ because burn-up is kept low to minimise the production of higher Pu isotopes (Mark, 1993).

$<$ Table 1 here $>$

\subsection{Atmospheric nuclear weapon tests}

Between 1945 and 1980, 543 atmospheric nuclear weapons tests (440 Mt total yield) were carried out worldwide with the most intense periods in 1952 - 1958 and in 1961 - 1962 (UNSCEAR, 2000a). Figure 1 shows the total annual yields (Mt per year) from atmospheric nuclear weapons tests together with the activity of ${ }^{90} \mathrm{Sr}$ deposited in the northern and southern hemispheres. The ${ }^{90} \mathrm{Sr}$ global fallout pattern is similar to that of Pu isotopes, with an average ${ }^{239+240} \mathrm{Pu} /{ }^{90} \mathrm{Sr}$ activity ratio in global fallout of about 0.025 (decay corrected to 2000) based on the normalised production rate for ${ }^{90} \mathrm{Sr}$ and $\mathrm{Pu}$ isotopes in nuclear explosions (UNSCEAR, 2000a; Aarkrog, 2003).

The low-yield fission weapons tests up to 1951 produced mainly tropospheric fallout that was deposited around the latitude band of the test sites (close-in fallout). From 1952 until the early 1960s, high-yield thermonuclear devices were tested and the fallout was spread worldwide (global fallout). Due to the distribution of the weapons tests locations the majority (ca. $76 \%$ ) of the fallout debris was deposited in the northern hemisphere (Fig. 1) with the highest deposition density between the 40 and $50^{\circ} \mathrm{N}$ latitudes (UNSCEAR, 2000a). 


\section{<Figure 1 here $>$}

It has been estimated that $12 \mathrm{PBq}$ of ${ }^{239+240} \mathrm{Pu}$ was deposited in the World Ocean from atmospheric nuclear weapons tests (Hamilton, 2005) and the resulting Pu isotope inventory is shown in Table 2. The Pu isotopic composition in the debris from nuclear detonations varies considerably and depends on the explosive yield, test site location and weapon type (Perkins and Thomas, 1980). The Pu isotopic composition in atmospheric fallout debris has changed over time due to changes in weapon design and yield, as demonstrated by ${ }^{240} \mathrm{Pu} /{ }^{239} \mathrm{Pu}$ time series analysis of samples from around the world (Koide et al., 1985; Leifer and Chan, 1997; Warneke et al., 2002; Olivier et al., 2004). The overall integrated ${ }^{240} \mathrm{Pu} /{ }^{239} \mathrm{Pu}$ atom ratio in global fallout debris is characterised by a ratio of $0.178 \pm 0.023$ (2 SD; $95 \%$ confidence level) (Kelley et al., 1999).

$<$ Table 2 here $>$

More than $70 \%$ of the global input of $\mathrm{Pu}$ from atmospheric nuclear weapons testing was from Novaya Zemlya (Russia) and the Marshall Islands (North Pacific). The Novaya Zemlya testing grounds were used mainly for large-scale atmospheric tests, with most of the debris injected into the stratosphere, and hence contributed mainly to the global fallout with only minor local marine contamination (Osvath et al., 1999; Oughton et al., 2004). However, a series of surface and underwater tests contributed significantly to elevated Pu levels in Chernaya Bay, off the southern coast of Novaya Zemlya. Approximately $11 \mathrm{TBq}$ of ${ }^{239+240} \mathrm{Pu}$ from the tests remains in Chernaya Bay sediments and still acts as a source to the Barents Sea, with an average ${ }^{240} \mathrm{Pu} /{ }^{239} \mathrm{Pu}$ atom ratio of about 0.03 , equivalent to low-yield nuclear detonations (Smith et al., 1995; Smith et al., 2000b). Most of the Marshall Islands tests were conducted near the surface, resulting in significant local and regional inputs of $\mathrm{Pu}$ to the marine environment (Buesseler, 1997; Robison and Noshkin, 1999). Debris from the first high-yield (Ivy Mike test, 15 Mt) thermonuclear detonation in 1952 at the Enewetak Atoll had 
$\mathrm{a}^{240} \mathrm{Pu} /{ }^{239} \mathrm{Pu}$ atom ratio of $0.363 \pm 0.004$ (Diamond et al., 1960). It has been estimated that debris from this detonation contributed about 5.1 PBq of ${ }^{239+240} \mathrm{Pu}$ to the local marine environment (Hamilton, 2005). Close-in fallout from the highest yield (Bravo test, $15 \mathrm{Mt}$ ) detonation performed at the Bikini Island in 1954 had a ${ }^{240} \mathrm{Pu} /{ }^{239} \mathrm{Pu}$ atom ratio of $0.33 \pm 0.06$ (Muramatsu et al., 2001). The main Pu contamination from these sites is buried in lagoon sediments ( $c a .90 \mathrm{TBq}{ }^{239+240} \mathrm{Pu}$ in 2000) which still act as a Pu source in the Pacific Ocean with an estimated annual ${ }^{239+240} \mathrm{Pu}$ export of about $0.2 \mathrm{TBq}^{-1}$ to the open ocean (Noshkin et al., 1987; Hamilton et al., 1996; Donaldson et al., 1997; Robison and Noshkin, 1999; Hamilton, 2005).

Other locations with significant input to the global or local marine environment include the Johnston Atoll and the Christmas Island (North Pacific), the Lop Nor site (China), the Mururoa and the Fangataufa Atolls (South Pacific), and the Semipalatinsk site (Kazakhstan). Contributions from other tests were very small or negligible (Livingston and Povinec, 2000). Overall, about $85 \%$ of the Pu injected into the atmosphere has been deposited globally and $15 \%$ locally or regionally (UNSCEAR, 2000a).

\subsection{Discharges from the nuclear industry}

When spent nuclear fuel is treated in nuclear reprocessing facilities low-level liquid radioactive wastes containing variable quantities of $\mathrm{Pu}$ are released into the marine environment. The nuclear reprocessing facilities in Sellafield (UK) and La Hague (France) in the North East Atlantic region are the most prominent sources. In the Arctic Ocean, a potential $\mathrm{Pu}$ source is run off from contaminated sediment in the $\mathrm{Ob}$ and Yenisey river system connected to the Mayak, Krasnoyarsk and Tomsk nuclear facilities and the Seimpalatinsk test site (Lind et al., 2006). Recent Pu analyses of sediment cores from the $\mathrm{Ob}$ and Yenisey estuaries showed ${ }^{240} \mathrm{Pu} /{ }^{239} \mathrm{Pu}$ atom ratios of about 0.11 and 0.18 , respectively, indicating 
contributions from both global fallout and the nuclear industry in the outflow to the Kara Sea (Skipperud et al., 2009).

Plutonium releases from other installations that may have influenced local $\mathrm{Pu}$ levels include Hanford plutonium production facility into the North East Pacific (Beasley and Jennings, 1984), Oak Ridge and Savannah River production plants into the West Atlantic (Carlton et al., 1996), Marcoule reprocessing plant in the Northwestern Mediterranean Sea (Miralles et al., 2004; Lansard et al., 2007), Rokkasho and Tokaimura nuclear reprocessing plants on the west coast of Japan (Yamada and Zheng, 2008), and Trombay and Tarapur nuclear reprocessing plants on the west coast of India. Other nuclear facilities that discharge liquid radioactive waste into the oceans, directly or indirectly, have made a less significant contribution to $\mathrm{Pu}$ contamination of the marine environment.

\section{$<$ Figure 2 here $>$}

Low-level liquid radioactive discharges from the Sellafield nuclear reprocessing plant on the coast of the Irish Sea in Cumbria, UK have been a major Pu source to the marine environment since 1952 (Kershaw et al., 2001). The total ${ }^{239+240} \mathrm{Pu}$ in liquid discharges (1952 2007) from the plant is about 0.6 PBq, with a peak in the early to mid-1970s (Fig. 2). The Pu isotopic composition of Sellafield effluents has varied over the years due to the different plant operations and the fuel reprocessed (Kershaw et al., 1995b). The complex was designed initially for the production of low burn-up weapons-grade Pu but focused later on reprocessing high burn-up spent fuel from commercial power reactors. Studies of dated sediment cores collected in the vicinity of the Sellafield plant showed ${ }^{240} \mathrm{Pu} /{ }^{239} \mathrm{Pu}$ atom ratios of 0.06 in the $1960 \mathrm{~s}$, corresponding to weapons-grade Pu, increasing to $>0.20$ in the $1980 \mathrm{~s}$, corresponding mainly to commercial spent fuel reprocessing (Fig. 2) (Kershaw et al., 1995a; Morris et al., 2000). A similar pattern was observed for the ${ }^{238} \mathrm{Pu} /{ }^{239+240} \mathrm{Pu}$ activity ratio, due to greater neutron capture by ${ }^{238} \mathrm{U}$ with longer burn-up times. Plutonium discharges from the 
Sellafield site decreased in the early 1980s but the Pu deposited in the Irish Sea sediment continues to act as a source for transport to the North Atlantic and the Arctic Ocean (Hunt and Kershaw, 1990; Cook et al., 1997; Kershaw et al., 1999a; Kershaw et al., 1999b). The estimated ${ }^{239+240} \mathrm{Pu}$ inventory in the seabed of the Irish Sea is in the range $440-560 \mathrm{TBq}$, with annual transport through the North Channel of $0.5-1.3 \mathrm{TBq}^{-1}$ (Cook et al., 1997; Jones et al., 1999; Kershaw et al., 1999a; Leonard et al., 1999). Recent model predictions support the view that the major $\mathrm{Pu}$ source in the Irish Sea is the contaminated sediments resulting from historical Sellafield discharges (Aldridge et al., 2003).

The Pu input from the La Hague site on the north coast of France has been small compared with the Sellafield site $(\sim 0.4 \%)$, with a total Pu release of $<0.005 \mathrm{PBq}$ (Kershaw and Baxter, 1995; Kershaw et al., 1995b; Nyffeler et al., 1996; Boust, 1999).

\subsection{Accidental releases}

The Chernobyl accident and incidents involving aircrafts and satellites have been the main accidental releases of $\mathrm{Pu}$ isotopes to the marine environment. The latter generally have local or regional impact but the SNAP-9A satellite incident had a wider footprint.

The Chernobyl accident in April 1986 has been the most serious accident involving a nuclear power reactor, with significant radionuclide fallout in the Northern Hemisphere. The explosions and subsequent fire released about $2.5 \mathrm{PBq}^{239+240} \mathrm{Pu}$ into the air, mostly deposited in the vicinity of the reactor (UNSCEAR, 2000b). The ${ }^{240} \mathrm{Pu} /{ }^{239} \mathrm{Pu}$ atom ratio from the Chernobyl fallout is about 0.38 (Table 1 ), which is considerably higher than the worldwideintegrated fallout ratio of $c a .0 .18$. The $\mathrm{Pu}$ input to the marine environment was reasonably small and mostly local, i.e. to the Baltic Sea and the Black Sea (Holm, 1995; Buesseler and Livingston, 1996). About $9 \%(1.5 \mathrm{TBq})$ of the total ${ }^{239+240} \mathrm{Pu}$ inventory in the Baltic Sea can 
be attributed to the Chernobyl accident (Holm, 1995).

In addition, $\mathrm{Pu}$ has been released into the marine environment from two accidents involving aircraft carrying nuclear weapons; in Palomares, Spain (1966) and in Thule, Greenland (1968) (Mitchell et al., 1997). In Thule, the Pu was dispersed locally after the chemical explosive components detonated on impact. Although an extensive clean-up operation was carried out on the ice around Thule immediately after the accident, the residual ${ }^{239+240} \mathrm{Pu}$ contamination of the marine environment was in the range $5-15 \mathrm{TBq}$ (Eriksson, 2002). Most of the Pu released from the Palomares accident was deposited on land and only a small fraction has been transferred to the marine environment, with a maximum estimated input of 1.4 TBq (Papucci et al., 1996; Sanchez-Cabeza et al., 2003). The characteristic ${ }^{240} \mathrm{Pu} /{ }^{239} \mathrm{Pu}$ atom ratio from both these sources was around 0.06 (Table 1), which corresponds well with ${ }^{240} \mathrm{Pu} /{ }^{239} \mathrm{Pu}$ atom ratio in weapons-grade $\mathrm{Pu}$.

In 1964, about $0.63 \mathrm{PBq}$ of ${ }^{238} \mathrm{Pu}$ was injected in the stratosphere from the burn-up of nuclear-powered SNAP-9A navigational satellite (Krey, 1967). Consequently, about $78 \%$ of the ${ }^{238} \mathrm{Pu}$ debris was deposited in the Southern Hemisphere, with the highest deposition between latitudes $20^{\circ} \mathrm{S}$ and $50{ }^{\circ} \mathrm{S}$ (Perkins and Thomas, 1980). The accident has contributed to the total inventory of ${ }^{238} \mathrm{Pu}$ in the World Ocean with an estimated input of ${ }^{238} \mathrm{Pu}$ of about 0.32 PBq decay corrected to the year 2000 (Hamilton, 2005). As a result of the SNAP-9A incident the average ${ }^{238} \mathrm{Pu} /{ }^{239+240} \mathrm{Pu}$ activity ratio in global fallout increased from $0.019 \pm$ 0.003 to $0.029 \pm 0.005$ in the Northern hemisphere and $0.14 \pm 0.04$ in the Southern hemisphere (values are decay corrected to 2000) (Perkins and Thomas, 1980).

\subsection{Other potential $\mathrm{Pu}$ inputs to the marine environment}

Nuclear-powered submarines lost at sea may be potential $\mathrm{Pu}$ sources to the marine 
environment. For example, the USSR Navy nuclear submarine "Kosmomolets" sank to a depth of $1700 \mathrm{~m}$ in the Barents Sea in 1989 with an estimated ${ }^{239} \mathrm{Pu}$ inventory of $21 \mathrm{TBq}$ (Livingston and Povinec, 2000). However, no Pu contamination from the submarine has yet been reported (Nies et al., 1999). Other potential accidental Pu sources include nuclear powered generators from the interplanetary station "Mars' $96 "\left(0.17 \mathrm{PBq}\right.$ of $\left.{ }^{238} \mathrm{Pu}\right)$ and Apollo $13\left(1.6 \mathrm{PBq}\right.$ of ${ }^{238} \mathrm{Pu}$ and $1.2 \mathrm{TBq}$ of ${ }^{239} \mathrm{Pu}$ ), both of which landed intact in the deep South Pacific Ocean (Dobry Jr, 1980; IAEA, 2001).

The dumping of radioactive wastes from the nuclear industry has been carried out at deep ocean sites, mainly in the North East Atlantic and the Arctic Oceans (IAEA, 1999), with only minor local Pu contamination (Livingston and Povinec, 2000). An estimated inventory of 8.9 $\mathrm{TBq}{ }^{239+240} \mathrm{Pu}$ in marine reactors was dumped in the Kara Sea (IAEA, 1998a) and enhanced levels of ${ }^{239+240} \mathrm{Pu}$ in close proximity to the objects indicates some leakage, but no evidence of any transfer from this site has been reported (Salbu et al., 1997; Nies et al., 1999). Radioactive dumping was also carried out in the western North Pacific Ocean and its marginal seas, but with considerably lower Pu inventories, and there is no evidence of elevated Pu from these sources (Livingston and Povinec, 2000). However, the lack of studies around these dumping sites makes it difficult to predict future Pu releases, especially in the Arctic Ocean (Nies et al., 1999; Osvath et al., 1999; Preller and Cheng, 1999; Skipperud, 2004). Nevertheless, these dumping sites may be potential Pu sources to the marine environment in the future.

\section{Behaviour of $\mathrm{Pu}$ in the marine environment}

The geochemical behaviour of $\mathrm{Pu}$ in the marine environment is influenced by: (i) the characteristics of the Pu source, (ii) its physico-chemical properties and (iii) biogeochemical 
and physical processes in the ocean.

Plutonium from a specific source may be associated with particles, colloids, pseudocolloids or low molecular mass species (Salbu, 2001) depending on the source and the environmental conditions. Global Pu fallout is mainly associated with sub-micron iron oxide particles, while Pu fallout from surface tests in the Marshall Islands was mainly attached to calcium hydroxide particles (Buesseler, 1997). In effluents from nuclear reprocessing plants most $\mathrm{Pu}$ is associated with particulate material or colloids (Leonard et al., 1995).

$<$ Figure 3 here $>$

The behaviour of $\mathrm{Pu}$ in seawater is influenced by a variety of geochemical processes, e.g. solubilisation, hydrolysis, complexation, sorption and colloid formation (Fig. 3). Microbial processes may also have a significant effect on the long-term behaviour and mobility of Pu (Francis, 2001; Francis et al., 2008). The oxidation state of Pu significantly affects its geochemical behaviour. In marine waters four different oxidation states exist, $\mathrm{Pu}(\mathrm{III}), \mathrm{Pu}(\mathrm{IV}), \mathrm{Pu}(\mathrm{V})$ and $\mathrm{Pu}(\mathrm{VI})$, with $\mathrm{Pu}(\mathrm{V})$ and $\mathrm{Pu}(\mathrm{IV})$ being the most common (Choppin, 2006). The $\mathrm{Pu}(\mathrm{IV})$ form is highly particle reactive and easily scavenged by suspended matter and colloids, while $\mathrm{Pu}(\mathrm{V})$ is relatively soluble and can be transported in the dissolved phase over long distances. Field studies in the Irish Sea and the Mediterranean Sea have shown that $\mathrm{Pu}(\mathrm{V})$ is the prevailing species in the dissolved phase and that particulate $\mathrm{Pu}$ is almost entirely in the reduced $\mathrm{Pu}(\mathrm{IV})$ form (Mitchell et al., 1995). In anoxic seawater Pu(III) is the dominant oxidation state (Sanchez et al., 1994). In general, Pu oxidation states in seawater are dependent on $\mathrm{pH}, \mathrm{E}_{\mathrm{H}}$ and the suspended particle concentration (Choppin, 2006).

Interaction with complexing agents and hydrolysis reactions are generally strongest for $\mathrm{Pu}(\mathrm{IV})$ and weakest for $\mathrm{Pu}(\mathrm{V})$, which leads to the preferential removal of reduced $\mathrm{Pu}$ species from solution by adsorption onto colloidal and suspended material (Nelson and Lovett, 1978; Orlandini et al., 1990; Mitchell et al., 1995). In contrast, oxidised Pu(V) has a high 
affinity for adsorption onto carbonate particles, e.g. corals, as surface complexes (Keeneykennicutt and Morse, 1985; Meece and Benninger, 1993; Gouzy et al., 2005b). Field studies of coastal seawater have shown that colloidal $\mathrm{Pu}(>1 \mathrm{kDa})$ is only a minor fraction of the total Pu in seawater (Dai et al., 2001; Mitchell et al., 2001).

In shallow waters with higher particle concentrations, preferential removal of Pu from the water column to the sediment takes place while in surface open ocean waters this process is dependent on biological productivity. Thus, in biologically poor (oligotrophic) regions the main component of the deposited Pu inventory from stratospheric fallout remains in the water column while in coastal waters almost all is removed from the water column to the seabed (León Vintró et al., 2005). Field studies in the oligotrophic western Mediterranean Sea indicate that $\mathrm{Pu}$ distribution in the upper water column is controlled by the degree of primary production (Fowler et al., 2000). However, close-in Pu fallout from the surface tests at the Marshall Islands had different physico-chemical characteristics, due to interaction with calcium-rich particles from the surrounding media, which resulted in a faster scavenging rate from surface waters to deep ocean sediment (Buesseler, 1997).

Sediment resuspension and dissolution influence the dispersion of $\mathrm{Pu}$ from contaminated sediment (Lansard et al., 2006). Plutonium is remobilised from contaminated sediment mainly in the oxidised forms $\mathrm{Pu}(\mathrm{V}, \mathrm{VI})$ as observed in the Irish Sea (Leonard et al., 1999; Mitchell et al., 2001). Various environmental factors may influence the remobilisation/uptake process such as $\mathrm{pH}$, temperature, light, bioirrigation, bioturbation and natural and anthropogenic physical mixing (McCubbin et al., 1999; Gouzy et al., 2005a; Kaplan et al., 2006). Laboratory studies suggested that only $0.02-1 \%$ of the total Pu in the sediment is available for remobilisation (McCubbin et al., 1999; McDonald et al., 2001). However, recent sequential extraction studies of Irish Sea sediment suggested that $\mathrm{Pu}$ is more bioavailable, with a release of at least $10 \%$ of the total Pu (Gouzy et al., 2005a). The study 
indicated that $\mathrm{Pu}$ is loosely bound to the sediment and is oxidised readily on contact with oxygen-rich waters.

The uptake of Pu into marine biota is dependent on the species and the surrounding environment (IAEA, 2004). Sediment-dwelling species play a significant role in the remobilisation process, as they may redistribute deposited $\mathrm{Pu}$ in the sediments by mixing and agitation (Ryan, 2002).

In summary, the scavenging rate of $\mathrm{Pu}$ in the marine environment depends on (i) the physical and chemical forms of $\mathrm{Pu}$; (ii) the amount of particulate matter; (iii) the settling rate of particles; (iv) mixing processes (e.g. diffusion, resuspension and bioturbation); and (v) biogeochemical processes (e.g. mineralogical transformations, redox reactions and uptake by biota).

\section{Use of Pu isotopes for studying marine processes}

Because of the unique sources (spatial and temporal) of Pu in the World Ocean and its nonconservative behaviour, the inventory is not uniformly distributed and Pu concentrations show significant variability around the world. The ${ }^{239+240} \mathrm{Pu}$ activity concentration in surface waters varies from a few $\mathrm{mBq} \mathrm{m}^{-3}$ in the open ocean up to $>100 \mathrm{mBq} \mathrm{m}^{-3}$ in semi-enclosed waters close to a Pu source (e.g. Irish Sea) (IAEA, 2005).

The main advantage of using $\mathrm{Pu}$ isotopes as tracers for marine processes is their welldefined source terms. The ${ }^{240} \mathrm{Pu} /{ }^{239} \mathrm{Pu}$ atom ratio from integrated global fallout $(\sim 0.18)$ is assumed to be uniformly distributed throughout the marine environment. For the calculation of the contribution of different sources with different Pu isotopic composition in marine samples, simple mixing models can be used (Kelley et al., 1999; Ketterer et al., 2004). In most marine regions Pu contamination consists mainly of contributions from global fallout 
and a local/regional source except in some cases such as the Baltic Sea (Holm, 1995) and the Arctic Ocean (Cooper et al., 2000). In general, the measured isotopic ratio, $\mathrm{R}_{\mathrm{S}}$, in a marine sample consists of contribution from n source terms and can be expressed as:

$$
\mathrm{R}_{\mathrm{S}}=\mathrm{x}_{1} \mathrm{R}_{1}+\mathrm{x}_{2} \mathrm{R}_{2}+\ldots+\mathrm{x}_{\mathrm{n}} \mathrm{R}_{\mathrm{n}}
$$

$$
\mathrm{x}_{1}+\mathrm{x}_{2}+\ldots+\mathrm{x}_{\mathrm{n}}=1
$$

where $x_{i}$ is the contribution from source term $i$ and $R_{i}$ is the isotopic ratio of source term $i$. In the case of two source terms the contribution $\left(\mathrm{x}_{1}\right)$ of source term (in $\left.\%\right)$ can be calculated by combining Eqs. (1) and (2) as follows:

$$
\mathrm{x}_{1}=100 \times\left(\mathrm{R}_{\mathrm{m}}-\mathrm{R}_{2}\right) /\left(\mathrm{R}_{1}-\mathrm{R}_{2}\right)
$$

where $R_{m}$ is the measured ratio. With the application of Eq. (3), a good estimation of the contribution of a particular source term can be helpful in understanding oceanographic processes, e.g. water mass exchange, in a specific marine region,. This has been applied in a number of marine studies such as estimation of the influence of Chernobyl Pu fallout to the Baltic Sea (Lindahl et al., 2005), the influence of the Pu-contaminated Rhone river input to the Mediterranean Sea (Miralles et al., 2004), the contribution of Pu debris from the Nevada Test Site in deep North West Atlantic waters (Buesseler and Sholkovitz, 1987), determination of the influence of underwater nuclear tests in the Bering Sea on the marine environment (Dasher et al., 2002), determination of the source of radioactivity in the Arctic Ocean (Huh et 
al., 1997; Cooper et al., 1999; Cooper et al., 2000), and estimation of the contribution of close-in fallout from the Marshall Islands to the Northwest Pacific Ocean and its marginal seas, and to the Indian Ocean (Zheng and Yamada, 2004; Lee et al., 2005; Wang and Yamada, 2005; Zheng and Yamada, 2005b; Yamada et al., 2006; Oikawa and Yamamoto, 2007; Yamada et al., 2007; Yamada and Zheng, 2008).

\subsection{Seawater studies}

Plutonium isotopes are effective as indicators for physical and biogeochemical processes in the water column. Plutonium in seawater is usually transported via advection, diffusion and particle scavenging. Many studies carried out in the open ocean water column have shown that $\mathrm{Pu}$ concentration depth profiles often show a pronounced sub-surface maximum (León Vintró et al., 2005). As an example, Figure 4 is showing ${ }^{239+240} \mathrm{Pu}$ depth profiles from different sites in the North Pacific Ocean. It has been suggested that this sub-surface maximum is related to vertical fluxes of $\mathrm{Pu}$-bearing particles and subsequent remineralisation by biological activity as well as physical circulation processes (Fowler et al., 2000; Livingston et al., 2001). Enhanced ${ }^{239+240} \mathrm{Pu}$ concentrations in deep bottom waters in the Pacific Ocean have been observed and this may be explained by rapid transport of $\mathrm{Pu}$ isotopes attached to large particles through the water column to deep ocean sediments and resuspension by near-bottom currents (Livingston and Anderson, 1983; Yamada and Aono, 2006). In shallow and coastal waters, the concentration of $\mathrm{Pu}$ is low as it is removed rapidly from the water column by particulate material.

\section{$<$ Figure 4 here $>$}

Zheng and Yamada (2006b) observed an increase in Pu flux with increased depth in the continental margins of Northwest Pacific by determining Pu concentrations in settling 
particles from sediment traps. They also found, from ${ }^{240} \mathrm{Pu} /{ }^{239} \mathrm{Pu}$ atom ratio analyses, that dissolved $\mathrm{Pu}$ is transported from the open ocean to ocean margins where $\mathrm{Pu}$ is removed into the margin sediments by scavenging. Scavenging has also been found to have a profound effect on the net annual outflow of ${ }^{239+240} \mathrm{Pu}$ from the Mediterranean Sea to the Atlantic, which has decreased by about one third from the amount estimated in 1988. This is due to the vertical transport of $\mathrm{Pu}$ and the consequent decrease of its concentration at intermediate depths (IAEA, 2005). Sediment trap studies have indicated that particles sinking through deep waters (1 $000-2000 \mathrm{~m}$ ) could account for $26 \%$ to $72 \%$ of the derived annual ${ }^{239+240} \mathrm{Pu}$ loss in the Mediterranean Sea (Fowler et al., 2000). The advection of deep water masses to the south-western part of the Mediterranean Sea from the Levantine Basin in the eastern Mediterranean has also been identified from the depth distributions of ${ }^{239+240} \mathrm{Pu}$ and ${ }^{238} \mathrm{Pu}$ together with ${ }^{137} \mathrm{Cs}$ (Noureddine et al., 2008).

Concentrations of ${ }^{239+240} \mathrm{Pu}$ and ${ }^{137} \mathrm{Cs}$ in surface seawater, coupled with oceanographic parameters, i.e. salinity and nutrient concentrations, have been utilised to demonstrate the exchange of surface water masses between different sea areas in the South Pacific Ocean (Hirose et al., 2007). By comparing the ${ }^{239+240} \mathrm{Pu} /{ }^{137} \mathrm{Cs}$ activity ratios in surface water with the global fallout ratio they found good correlations between ${ }^{239+240} \mathrm{Pu}$ concentrations and particle scavenging rates, which provided additional evidence to support the suggested exchange processes. A similar approach was applied to vertical profiles of the ${ }^{239+240} \mathrm{Pu} /{ }^{137} \mathrm{Cs}$ activity ratios in shallow waters of the North Pacific (Hirose et al., 2009). Depth profiles of ${ }^{239+240} \mathrm{Pu} /{ }^{137} \mathrm{Cs}$ were expressed by a simple exponential function reflecting export and regeneration processes.

In addition, speciation studies have shown that the ratio between oxidised and reduced forms of Pu may be a valuable tracer for lateral water movement processes (Baxter et al., 1995). The ${ }^{238} \mathrm{Pu} /{ }^{239+240} \mathrm{Pu}$ activity ratio and $\mathrm{Pu}$ oxidation state ratio in the water column of 
two Norwegian Fjords were used as a tracer for water exchange between the fjords and the North Sea (Sanchez et al., 1994).

\subsection{Sediment studies}

Marine sediments are major repositories of organic matter and pollutants that are embedded in the sediment layers. Understanding the dispersion and fate of these contaminants is of great importance due to their influence on global biogeochemical cycles and marine processes (Hedges and Keil, 1995).

There have been a large number of studies of $\mathrm{Pu}$ in marine sediments, including the dynamics of mixing processes and accumulation rates. Sediment studies usually include $\mathrm{Pu}$ isotopes in combination with other radionuclides or stable isotopes (e.g. Krishnaswami et al., 1980; Santschi et al., 1980; Benninger and Krishnaswami, 1981; Cochran, 1985; Smith et al., 1986; Carpenter et al., 1987; Lapicque et al., 1987; Buffoni et al., 1992; Huh et al., 1997; Huh and Su, 1999; Smith et al., 2000b; Gascó et al., 2002; Su and Huh, 2002; Moon et al., 2003; Garcia-Orellana et al., 2009). Knowledge of particle mixing rates in sediments is essential for deconvoluting different depth-dependent sediment processes that could influence the distribution of chemical pollutants. The various Pu studies in marine sediments have contributed to developing sediment mixing models with constant, continuous, or pulsed $\mathrm{Pu}$ inputs (Smith et al., 1995; Smith et al., 2000b; Moon et al., 2003).

The deposition of $\mathrm{Pu}$ in shelf or slope environments is controlled by the extent of scavenging in the upper water layers. Hence, the depth distribution of Pu is often a measure of historical Pu-flux in the water column. In areas with negligible mixing compared to sediment accumulation, global fallout ${ }^{239+240} \mathrm{Pu}$ (with distinct peak at around 1964), in combination with the well-established ${ }^{210} \mathrm{~Pb}$ dating methodology, in sediment cores can be used to estimate the 
past flux of particulate material. For example, high particle flux events were observed in the continental margin of the East China Sea by determining ${ }^{239+240} \mathrm{Pu}$ and natural radionuclides in settling particles and surface sediment (Yamada and Aono, 2002; 2006). These high flux events were attributed to episodic lateral transport of resuspended particles that flow down the continental slope with the nepheloid layer.

Studies of $\mathrm{Pu}$ and natural radionuclides association with particulate matter in the ocean have considerably advanced understanding of the ocean carbon cycle and ocean particle mixing (Bacon et al., 1985). The sinking of Pu-bearing particles ( $\mathrm{Pu}$-flux) in the upper euphotic zone is closely coupled with the carbon flux (Baxter et al., 1995) and scavenging of trace metals (Hirose et al., 1992). The techniques developed for the study of particle associated $\mathrm{Pu}$ in the ocean were used in the Joint Global Ocean Flux Study (JGOFS) (Livingston and Povinec, 2002). Plutonium isotopes have also been used at a seasonal polynia off the northeast coast of Greenland to evaluate the carbon cycle and to improve the estimation of the particulate organic carbon flux. In this study, the ${ }^{239+240} \mathrm{Pu}$ depth distribution in sediment was used as an indicator of particle mixing, with accumulation rates estimated from ${ }^{210} \mathrm{~Pb}$ (Roberts et al., 1997).

Distribution and transport of particulate matter in riverine inputs to coastal waters can be estimated by using Pu isotopes in sediments contaminated with various identified sources such as global fallout and nuclear facilities linked to the river (Olsen et al., 1989; Thomas, 1997; Eyrolle et al., 2004; Miralles et al., 2004; Duffa and Renaud, 2005; Lansard et al., 2007). For example, Oktay et al. (2000) found a five-fold decrease in riverine particle discharges into the Gulf of Mexico from the Mississippi River prior to the early 1960, by applying Pu isotopes in combination with excess ${ }^{210} \mathrm{~Pb}$ in determination of an ${ }^{129} \mathrm{I}$ chronology record.

Another approach for dating of deep-sea sediments may be the use of ${ }^{241} \mathrm{Pu}$ and 
${ }^{241} \mathrm{Am}$ concentrations in the sediment layers with the assumption that all ${ }^{241} \mathrm{Am}$ is produced from ingrowth of ${ }^{241} \mathrm{Pu}$ (Lee et al., 2005).

\subsection{Retrospective studies}

In research on global climate change, retrospective studies on past ocean conditions are based mainly on isotopic analyses of natural archives in the marine environment, including sediments, corals and other marine biota. These natural archives (proxies) provide information regarding historical chemical and physical conditions in the surrounding seawater. Isotopic analyses of annual bands from corals has provided sensitive time series of past ocean chemistry, ocean circulation and climate (Druffel, 1997). As the Pu isotopic composition differs from each source, retrospective studies of $\mathrm{Pu}$ may provide valuable information on past ocean circulation and aid understanding of the biogeochemical cycles of oceanic carbon, particle-reactive nutrients and pollutants.

Dated coral cores have been used to retrieve historical records of Pu isotopes from global and close-in fallout in the surrounding seawater and thereby provide information about source terms, water mass movement, and the geochemical behaviour of $\mathrm{Pu}$ in the marine environment (Noshkin et al., 1975; Benninger and Dodge, 1986; Purdy et al., 1989; Buesseler, 1997). Plutonium concentrations in accumulating corals are in equilibrium with surrounding water and the determination of $\mathrm{Pu}$ in corals provides a better annual resolution than sediment due to better accumulation rates with distinct seasonal features and negligible mixing between the growth layers.

In the Pacific Ocean, the North Equatorial Current (NEC) and the Kuroshio Current are important currents that supply the Northwest Pacific with warm surface water from the Equatorial Pacific. The Marshall Islands, located in the path of NEC, continuously releases 
about $0.2 \mathrm{TBq}$ of ${ }^{239+240} \mathrm{Pu}$ annually from contaminated sediment into the open ocean (see Section 2.1). By determining ${ }^{240} \mathrm{Pu} /{ }^{239} \mathrm{Pu}$ atom ratios in sediment and seawater it has been suggested that $\mathrm{Pu}$ from the Marshall Islands is transported by the westward-flowing NEC and onwards by the Kuroshio Current up to the Northwest Pacific Ocean and its marginal seas (Kim et al., 2004; Zheng and Yamada, 2004; Lee et al., 2005; Wang and Yamada, 2005; Zheng and Yamada, 2005b; Zheng and Yamada, 2006a; Yamada et al., 2007; Yamada and Zheng, 2008). This hypothesis was recently proposed from elevated ${ }^{240} \mathrm{Pu} /{ }^{239} \mathrm{Pu}$ atom ratios in squid liver samples collected from the western and eastern coastal areas of Japan (Kishimoto et al., 2002; Oikawa and Yamamoto, 2007). The high ${ }^{240} \mathrm{Pu} /{ }^{239} \mathrm{Pu}$ atom ratios (> 0.20) observed in these studies indicate a contribution from the Marshall Islands source since the tropospheric $\mathrm{Pu}$ fallout from the Marshall Islands tests can be assumed to be negligible in these waters (Huh, 1997; Zheng and Yamada, 2005a). Figure 5 shows a time series of ${ }^{240} \mathrm{Pu} /{ }^{239} \mathrm{Pu}$ atom ratios in sediment and coral from three sites in the Pacific Ocean. There are indications that the flow of the Kuroshio Current has been disrupted due to global climate change (Sato et al., 2006). Therefore, by tracking the distinct Pu signal from the Marshall Islands in this area, past current flows can be retrospectively studied and the potential coupling with recent climate change can be elucidated.

\section{$<$ Figure 5 here $>$}

The surface current transit time from the Marshall Islands to the marginal areas of the Northwest Pacific was estimated to be six years by analysing ${ }^{239+240} \mathrm{Pu}$ and the ${ }^{240} \mathrm{Pu} /{ }^{239} \mathrm{Pu}$ atom ratio in sediments from the Southern Okinawa Trough (Lee et al., 2004). From this estimation, the mean velocity of NEC was calculated to be $\sim 0.022 \mathrm{~m} \mathrm{~s}^{-1}$, which corresponds well with the annual mean velocity, which is in the range $0.02-0.06 \mathrm{~m} \mathrm{~s}^{-1}$.

Another potential proxy for historical Pu records is the use of dated mollusc shells that contain calcium carbonate. For example, Baskaran et al. (2005) used archived bivalve 
shells for reconstructing historical global fallout of ${ }^{90} \mathrm{Sr}$ levels in shallow coastal waters.

Plutonium isotopes and ${ }^{129} \mathrm{I}$ in archived marine algae have been utilised as historical indicators for the transport of seawater contaminated with radioactive waste from nuclear fuel reprocessing plants to the North Atlantic and Arctic Ocean (Cooper et al., 1998).

\subsection{Other applications of $\mathrm{Pu}$ isotopes in the marine environment}

Sea ice transport is an important factor for the long range dispersal of contaminants in the Arctic Ocean and into the North Atlantic because melting releases contaminants from the ice (Pfirman et al., 1995). Plutonium isotopes $\left({ }^{239} \mathrm{Pu}\right.$ and ${ }^{240} \mathrm{Pu}$ ), together with other natural and anthropogenic radionuclides, have been used to track sea ice transport through the Arctic Ocean and to estimate transit times from the source to the removal area (Landa et al., 1998; Masqué et al., 2003; Masqué et al., 2007).

Atmospheric inputs of mineral aerosol into the ocean affect biogeochemical processes in the water column. A method for estimating the mineral aerosol flux to the Pacific Ocean using ${ }^{239+240} \mathrm{Pu}$ as a tracer was developed by utilising ${ }^{239+240} \mathrm{Pu}$ concentrations in surface waters and airborne dust together with $\mathrm{Pu}$ residence time and mixed layer depth (Nakanishi et al., 1995).

There is an increasing demand for validated regional and global marine ecosystem models, as well as ocean circulation models for the prediction of future global environmental changes, and the unique chemical properties of $\mathrm{Pu}$, together with its well-defined source terms, will provide important information for the evaluation and improvement of these models. 


\section{Conclusions}

The overall input of Pu to the World Ocean has declined significantly in the last four decades, mainly due to the cessation of atmospheric weapons tests. However, due to the long half-life and unique chemical properties of $\mathrm{Pu}$, it will persist in the marine environment for a long time. Due to the well-defined source terms, $\mathrm{Pu}$ isotopes can be utilised in marine research for the study of oceanic processes such as water mass movement, particle export and sediment mixing and accumulation rates. Plutonium isotope data can be used for calibrating and validating numerical models for pollutant dispersion in the marine environment and ocean current circulation (Smith et al., 2000a; Nakano and Povinec, 2003; Tsumune et al., 2003). In view of the increasing concerns relating to global climate change and its impact on the marine environment, the historical Pu signal in natural archives (e.g. sediments and biota) will enhance our understanding of important biogeochemical and physical processes in the ocean. Reconstructed $\mathrm{Pu}$ signatures in natural archive marine samples will also provide valuable information on the impact of past climate change on ocean mixing and support the validation and calibration of ocean circulation models.

\section{Acknowledgements}

This work was financially supported under the European Commission $7^{\text {th }}$ Framework, Marie Curie International Outgoing Fellowship Research Project PIOF-GA-2008-219625 "PLUTOTRACE". 


\section{References}

Aarkrog, A., 2003. Input of anthropogenic radionuclides into the World Ocean. Deep Sea Research Part II: Topical Studies in Oceanography 50, 2597-2606.

Aldridge, J.N., Kershaw, P., Brown, J., McCubbin, D., Leonard, K.S., Young, E.F., 2003. Transport of plutonium $\left({ }^{239 / 240} \mathrm{Pu}\right)$ and caesium $\left({ }^{137} \mathrm{Cs}\right)$ in the Irish Sea: comparison between observations and results from sediment and contaminant transport modelling. Continental Shelf Research 23, 869-899.

Bacon, M.P., Huh, C.-A., Fleer, A.P., Deuser, W.G., 1985. Seasonality in the flux of natural radionuclides and plutonium in the deep Sargasso Sea. Deep Sea Research Part A. Oceanographic Research Papers 32, 273-286.

Baskaran, M., Hong, G.-H., Kim, S.-H., Wardle, W.J., 2005. Reconstructing seawater column ${ }^{90} \mathrm{Sr}$ based upon ${ }^{210} \mathrm{~Pb} /{ }^{226} \mathrm{Ra}$ disequilibrium dating of mollusk shells. Applied Geochemistry 20, 1965-1973.

Baxter, M.S., Fowler, S.W., Povinec, P.P., 1995. Observations on plutonium in the oceans. Applied Radiation and Isotopes 46, 1213-1223.

Beasley, T.M., Jennings, C.D., 1984. The inventories of plutonium-239, -240, americium-241, cesium-137, and cobalt-60 in Columbia River sediments from Hanford to the Columbia River Estuary. Environmental Science \& Technology 18, 207-212.

Beasley, T.M., Kelley, J.M., Orlandini, K.A., Bond, L.A., Aarkrog, A., Trapeznikov, A.P., Pozolotina, V.N., 1998. Isotopic Pu, U, and Np signatures in soils from Semipalatinsk21, Kazakh Republic and the Southern Urals, Russia. Journal of Environmental Radioactivity 39, 215-230.

Benninger, L.K., Dodge, R.E., 1986. Fallout plutonium and natural radionuclides in annual bands of the coral Montastrea annularis, St. Croix, U.S. Virgin Islands. Geochimica et Cosmochimica Acta 50, 2785-2797.

Benninger, L.K., Krishnaswami, S., 1981. Sedimentary processes in the inner New York Bight: Evidence from excess ${ }^{210} \mathrm{~Pb}$ and ${ }^{239,240} \mathrm{Pu}$. Earth and Planetary Science Letters 53, 158174.

BNFL, 2002. Discharges and Monitoring of the Environment in the UK, British Nuclear Fuels plc, Environment Health Safety and Quality, Warrington, UK, 159 pp.

BNFL, 2007. Discharges and Monitoring in the United Kingdom, Annual Report 2007, Sellafield Ltd, British Nuclear Fuels plc, Cumbria, UK, 64 pp.

Børretzen, P., Standring, W.J.F., Oughton, D.H., Dowdall, M., Fifield, L.K., 2005. Pu and U atom ratios and concentration factors in Reservoir 11 and Asanov Swamp, Mayak PA: an application of Accelerator Mass Spectrometry. Environmental Science \& Technology 39, 92-97.

Boulyga, S.F., Becker, J.S., 2002. Isotopic analysis of uranium and plutonium using ICP-MS and estimation of burn-up of spent uranium in contaminated environmental samples. Journal of Analytical Atomic Spectrometry 17, 1143-1147.

Boulyga, S.F., Erdmann, N., Funk, H., Kievets, M.K., Lomonosova, E.M., Mansel, A., Trautmann, N., Yaroshevich, O.I., Zhuk, I.V., 1997. Determination of isotopic composition of plutonium in hot particles of the Chernobyl area. Radiation Measurements 28, 349-352. 
Boust, D., 1999. Distribution and inventories of some artificial and naturally occurring radionuclides in medium to coarse-grained sediments of the channel. Continental Shelf Research 19, 1959-1975.

Bowen, V.T., Noshkin, V.E., Livingston, H.D., Volchok, H.L., 1980. Fallout radionuclides in the Pacific Ocean: Vertical and horizontal distributions, largely from GEOSECS stations. Earth and Planetary Science Letters 49, 411-434.

Buesseler, K.O., 1997. The isotopic signature of fallout plutonium in the North Pacific. Journal of Environmental Radioactivity 36, 69-83.

Buesseler, K.O., Livingston, H.D., 1996. Natural and man-made radionuclides in the Black Sea. In: Guegueniat, P., Germain, P. and Metivier, H. (Eds), Radionuclides in the Oceans, Inputs and Inventories. Les Editions de Physique, Paris, France, pp. 199-217.

Buesseler, K.O., Sholkovitz, E.R., 1987. The geochemistry of fallout plutonium in the North Atlantic: II. ${ }^{240} \mathrm{Pu} /{ }^{239} \mathrm{Pu}$ ratios and their significance. Geochimica et Cosmochimica Acta 51, 2623-2637.

Buffoni, G., Delfanti, R., Papucci, C., 1992. Accumulation rates and mixing processes in nearsurface North Atlantic sediments: Evidence from C-14 and Pu-239,240 downcore profiles. Marine Geology 109, 159-170.

Carlton, W.H., Murphy Jr, C.E., Evans, A.G., 1996. Plutonium in the Savannah River Site environment. Health Physics 71, 290-299.

Carpenter, R., Beasley, T.M., Zahnle, D., Somayajulu, B.L.K., 1987. Cycling of fallout (Pu, $\left.{ }^{241} \mathrm{Am},{ }^{137} \mathrm{Cs}\right)$ and natural $\left(\mathrm{U}, \mathrm{Th},{ }^{210} \mathrm{~Pb}\right)$ radionuclides in Washington continental slope sediments. Geochimica et Cosmochimica Acta 51, 1897-1921.

Chamizo, E., García-León, M., Synal, H.A., Suter, M., Wacker, L., 2006. Determination of the ${ }^{240} \mathrm{Pu} /{ }^{239} \mathrm{Pu}$ atomic ratio in soils from Palomares (Spain) by low-energy accelerator mass spectrometry. Nuclear Instruments and Methods in Physics Research Section B: Beam Interactions with Materials and Atoms 249, 768-771.

Chiappini, R., Pointurier, F., Millies-Lacroix, J.C., Lepetit, G., Hemet, P., 1999. ${ }^{240} \mathrm{Pu} /{ }^{239} \mathrm{Pu}$ isotopic ratios and ${ }^{239+240} \mathrm{Pu}$ total measurements in surface and deep waters around Mururoa and Fangataufa atolls compared with Rangiroa atoll (French Polynesia). Science of The Total Environment 237-238, 269-276.

Choppin, G.R., 2006. Actinide speciation in aquatic systems. Marine Chemistry 99, 83-92.

Choppin, G.R., Morgenstern, A., 2001. Distribution and movement of environmental plutonium. In: Kudo, A. (Editor), Plutonium in the Environment. Radioactivity in the Environment. Elsevier, pp. 91-105.

Cochran, J.K., 1985. Particle mixing rates in sediments of the eastern equatorial Pacific: evidence from ${ }^{210} \mathrm{~Pb},{ }^{239,240} \mathrm{Pu}$ and ${ }^{137} \mathrm{Cs}$ distributions at MANOP sites. Geochimica et Cosmochimica Acta 49, 1195-1210.

Cook, G.T., MacKenzie, A.B., McDonald, P., Jones, S.R., 1997. Remobilization of Sellafieldderived radionuclides and transport from the North-east Irish Sea. Journal of Environmental Radioactivity 35, 227-241.

Cooper, L.W., Beasley, T., Aagaard, K., Kelley, J.M., Larsen, I.L., Grebmeier, J.M., 1999. Distributions of nuclear fuel-reprocessing tracers in the Arctic Ocean: indications of Russian river infuence. Journal of Marine Research 57, 715-738.

Cooper, L.W., Beasley, T.M., Zhao, X.L., Soto, C., Vinogradova, K.L., Dunton, K.H., 1998. 
Iodine-129 and plutonium isotopes in Arctic kelp as historical indicators of transport of nuclear fuel-reprocessing wastes from mid-to-high latitudes in the Atlantic Ocean. Marine Biology 131, 391-399.

Cooper, L.W., Kelley, J.M., Bond, L.A., Orlandini, K.A., Grebmeier, J.M., 2000. Sources of the transuranic elements plutonium and neptunium in arctic marine sediments. Marine Chemistry 69, 253-276.

Dahlgaard, H., 1995. Transfer of European coastal pollution to the arctic: radioactive tracers. Marine Pollution Bulletin 31, 3-7.

Dai, M.H., Buesseler, K.O., Kelley, J.M., Andrews, J.E., Pike, S., Wacker, J.F., 2001. Sizefractionated plutonium isotopes in a coastal environment. Journal of Environmental Radioactivity 53, 9-25.

Danesi, P., Moreno, J., Makarewicz, M., Radecki, Z., 2002. Residual radioactivity in the terrestrial environment of the Mururoa and Fangataufa Atolls nuclear weapon test sites. Journal of Radioanalytical and Nuclear Chemistry 253, 53-65.

Dasher, D., Hanson, W., Read, S., Faller, S., Farmer, D., Efurd, W., Kelley, J., Patrick, R., 2002. An assessment of the reported leakage of anthropogenic radionuclides from the underground nuclear test sites at Amchitka Island, Alaska, USA to the surface environment. Journal of Environmental Radioactivity 60, 165-187.

Diamond, H., Fields, P.R., Stevens, C.S., Studier, M.H., Fried, S.M., Inghram, M.G., Hess, D.C., Pyle, G.L., Mech, J.F., Manning, W.M., Ghiorso, A., Thompson, S.G., Higgins, G.H., Seaborg, G.T., Browne, C.I., Smith, H.L., Spence, R.W., 1960. Heavy isotope abundances in Mike thermonuclear device. Physical Review 119, 2000-2004.

Dobry Jr, T.J., 1980. Transuranic elements in space nuclear power systems. In: Hanson, W.C. (Editor), Transuranic Elements in the Environment. US DOE/TIC-22800, U.S.

Department of Energy, Office of Health and Environmental Research, pp. 83-85.

Donaldson, L.R., Seymour, A.H., Nevissi, A.E., 1997. University of Washington's radioecological studies in the Marshall Islands, 1946-1977. Health Physics 73, 214222.

Druffel, E.R.M., 1997. Geochemistry of corals: proxies of past ocean chemistry, ocean circulation, and climate. Proceedings of the National Academy of Sciences of the United States of America 94, 8354-8361.

Duffa, C., Renaud, P., 2005. 238Pu and 239+240Pu inventory and distribution through the lower Rhone valley terrestrial environment (Southern France). Science of The Total Environment 348, 164-172.

Eriksson, M., 2002. On weapons plutonium in the Arctic environment (Thule, Greenland). Risoe-R-1321(EN), Risoe National Laboratory, Roskilde, Denmark, 150 pp.

Eriksson, M., Lindahl, P., Roos, P., Dahlgaard, H., Holm, E., 2008. U, Pu, and Am nuclear signatures of the Thule hydrogen bomb debris. Environmental Science \& Technology $42,4717-4722$.

Eyrolle, F., Charmasson, S., Louvat, D., 2004. Plutonium isotopes in the lower reaches of the River Rhône over the period 1945-2000: fluxes towards the Mediterranean Sea and sedimentary inventories. Journal of Environmental Radioactivity 74, 127-138.

Fowler, S.W., Noshkin, V.E., Rosa, J.L., Gastaud, J., 2000. Temporal variations in plutonium and americium inventories and their relation to vertical transport in the Northwestern 
Mediterranean Sea. Limnology and Oceanography 45, 446-458.

Francis, A.J., 2001. Microbial transformations of plutonium and implications for its mobility. In: Kudo, A. (Editor), Plutonium in the Environment. Radioactivity in the Environment. Elsevier, pp. 201-219.

Francis, A.J., Dodge, C.J., Gillow, J.B., 2008. Reductive dissolution of Pu(IV) by Clostridium sp. under anaerobic conditions. Environmental Science \& Technology 42, 2355-2360.

Garcia-Orellana, J., Pates, J.M., Masqué, P., Bruach, J.M., Sanchez-Cabeza, J.A., 2009. Distribution of artificial radionuclides in deep sediments of the Mediterranean Sea. Science of The Total Environment 407, 887-898.

Gascó, C., Antón, M.P., Pozuelo, M., Meral, J., González, A.M., Papucci, C., Delfanti, R., 2002. Distributions of $\mathrm{Pu}, \mathrm{Am}$ and $\mathrm{Cs}$ in margin sediments from the western Mediterranean (Spanish coast). Journal of Environmental Radioactivity 59, 75-89.

Gauthier-Lafaye, F., Pourcelot, L., Eikenberg, J., Beer, H., Le Roux, G., Rhikvanov, L.P., Stille, P., Renaud, P., Mezhibor, A., 2008. Radioisotope contaminations from releases of the Tomsk-Seversk nuclear facility (Siberia, Russia). Journal of Environmental Radioactivity 99, 680-693.

Gouzy, A., Boust, D., Connan, O., Billon, G., Vintró, L.L., Lucey, J., Bowden, L., Agarande, M., Lesourd, S., Lesueur, P., Klein, A., Kershaw, P.J., Mitchell, P.I., 2005a. Diagenetic reactivity of the plutonium in marine anoxic sediments (Cumbrian mud patch - eastern Irish Sea). Radioprotection 40, S541-S547.

Gouzy, A., Boust, D., Connan, O., Klein, A., Rozet, M., Solier, L., 2005b. Post-depositional reactivity of the plutonium in different sediment facies from the English Channel - an experimental approach. Radioprotection 40, S613-S619.

Gray, J., Jones, S.R., Smith, A.D., 1995. Discharges to the environment from the Sellafield site, 1951-1992. Journal of Radiological Protection 15, 99-131.

Hamilton, T.F., 2005. Linking legacies of the Cold War to arrival of anthropogenic radionuclides in the oceans through the 20th century. In: Livingston, H.D. (Editor), Marine Radioactivity. Radioactivity in the Environment. Elsevier, pp. 23-78.

Hamilton, T.F., Millies-Lacroix, J., Hong, G.H., 1996. ${ }^{137} \mathrm{Cs}\left({ }^{90} \mathrm{Sr}\right)$ and Pu isotopes in the Pacific Ocean: Sources and trends. In: Guegueniat, P., Germain, P. and Metivier, H. (Eds), Radionuclides in the Oceans, Inputs and Inventories. Les Editions de Physique, Paris, France, pp. 29-58.

Hedges, J.I., Keil, R.G., 1995. Sedimentary organic matter preservation: an assessment and speculative synthesis. Marine Chemistry 49, 81-115.

Hicks, H.G., Barr, D.W., 1984. Nevada test site fallout atom ratios: ${ }^{240} \mathrm{Pu} /{ }^{239} \mathrm{Pu}$ and ${ }^{241} \mathrm{Pu} /{ }^{239} \mathrm{Pu}$. UCRL-53499/1, Lawrence Livermore National Laboratory, USA, 5 pp.

Hirose, K., Aoyama, M., Fukasawa, M., Kim, C.S., Komura, K., Povinec, P.P., SanchezCabeza, J.A., 2007. Plutonium and ${ }^{137} \mathrm{Cs}$ in surface water of the South Pacific Ocean. Science of The Total Environment 381, 243-255.

Hirose, K., Aoyama, M., Povinec, P.P., 2009. ${ }^{239,240} \mathrm{Pu} /{ }^{137} \mathrm{Cs}$ ratios in the water column of the North Pacific: a proxy of biogeochemical processes. Journal of Environmental Radioactivity 100, 258-262.

Hirose, K., Sugimura, Y., Aoyama, M., 1992. Plutonium and ${ }^{137}$ Cs in the western North Pacific: estimation of residence time of plutonium in surface waters. International 
Journal of Radiation Applications and Instrumentation. Part A. Applied Radiation and Isotopes 43, 349-359.

Holm, E., 1995. Plutonium in the Baltic Sea. Applied Radiation and Isotopes 46, 1225-1229.

Hrnecek, E., Steier, P., Wallner, A., 2005. Determination of plutonium in environmental samples by AMS and alpha spectrometry. Applied Radiation and Isotopes 63, 633-638.

Huh, C.-A., Pisias, N.G., Kelley, J.M., Maiti, T.C., Grantz, A., 1997. Natural radionuclides and plutonium in sediments from the western Arctic Ocean: sedimentation rates and pathways of radionuclides. Deep Sea Research Part II: Topical Studies in Oceanography 44, 1725-1743.

Huh, C.-A., Su, C.-C., 1999. Sedimentation dynamics in the East China Sea elucidated from ${ }^{210} \mathrm{~Pb},{ }^{137} \mathrm{Cs}$ and ${ }^{239,240} \mathrm{Pu}$. Marine Geology 160, 183-196.

Huh, C.A., $1997 .{ }^{240} \mathrm{Pu} /{ }^{239} \mathrm{Pu}$ ratios in Sun Moon lake sediments: implications for sources of nuclear fallout in Taiwan. Terrestrial, Atmospheric and Oceanic Sciences 8, 289-294.

Hunt, G.J., Kershaw, P.J., 1990. Remobilisation of artificial radionuclides from the sediment of the Irish Sea. Journal of Radiological Protection 10, 147-151.

IAEA, 1998a. Radiological conditions of the western Kara Sea: Assessment of the radiological impact of the dumping of radioactive waste in the Arctic Sea. Report on the international Arctic Seas assessment project (IASAP), International Atomic Energy Agency, Austria, Vienna, 127 pp.

IAEA, 1998b. The radiological situation at the atolls of Mururoa and Fangataufa. Main report, Inernational Atomic Energy Agency, Vienna, Austria, 310 pp.

IAEA, 1999. Inventory of Radioactive Waste Disposals at Sea. IAEA-TECDOC-1105, International Atomic Energy Agency, Vienna, Austria, 127 pp.

IAEA, 2001. Inventory of accidents and losses at sea involving radioactive material. IAEATECDOC-1242, International Atomic Energy Agency, Vienna, Austria, 76 pp.

IAEA, 2004. Sediment distribution coefficients and concentration factors for biota in the marine environment. Technical Report Series No. 422, International Atomic Energy Agency, 103 pp.

IAEA, 2005. Worldwide Marine Radioactivity Studies (WOMARS): Radionuclide Levels in Oceans and Seas. IAEA-TECDOC-1429, International Atomic Energy Agency, Vienna, Austria, 194 pp.

Jiménez-Ramos, M.C., Barros, H., García-Tenorio, R., García-León, M., Vioque, I., Manjón, G., 2007. On the presence of enriched amounts of ${ }^{235} \mathrm{U}$ in hot particles from the terrestrial area affected by the Palomares accident (Spain). Environmental Pollution $145,391-394$.

Jones, D.G., Roberts, P.D., Strutt, M.H., Higgo, J.J., Davis, J.R., 1999. Distribution of ${ }^{137}$ Cs and inventories of ${ }^{238} \mathrm{Pu},{ }^{239 / 240} \mathrm{Pu},{ }^{241} \mathrm{Am}$ and ${ }^{137} \mathrm{Cs}$ in Irish Sea intertidal sediments. Journal of Environmental Radioactivity 44, 159-189.

Kaplan, D.I., Powell, B.A., Gumapas, L., Coates, J.T., Fjeld, R.A., Diprete, D.P., 2006. Influence of $\mathrm{pH}$ on plutonium desorption/solubilization from sediment. Environmental Science \& Technology 40, 5937-5942.

Keeney-kennicutt, W.L., Morse, J.W., 1985. The redox chemistry of $\mathrm{Pu}(\mathrm{V}) \mathrm{O}_{2}{ }^{+}$interaction with common mineral surfaces in dilute solutions and seawater. Geochimica et 
Cosmochimica Acta 49, 2577-2588.

Kelley, J.M., Bond, L.A., Beasley, T.M., 1999. Global distribution of Pu isotopes and ${ }^{237} \mathrm{~Np}$. Science of The Total Environment 237-238, 483-500.

Kershaw, P., Baxter, A., 1995. The transfer of reprocessing wastes from north-west Europe to the Arctic. Deep Sea Research Part II: Topical Studies in Oceanography 42, 1413-1448.

Kershaw, P., Sampson, K., McCarthy, W., Scott, R., 1995a. The measurement of the isotopic composition of plutonium in an Irish Sea sediment by mass spectrometry. Journal of Radioanalytical and Nuclear Chemistry 198, 113-124.

Kershaw, P.J., Denoon, D.C., Woodhead, D.S., 1999a. Observations on the redistribution of plutonium and americium in the Irish Sea sediments, 1978 to 1996: concentrations and inventories. Journal of Environmental Radioactivity 44, 191-221.

Kershaw, P.J., Leonard, K.S., McCubbin, D., Aldridge, J.N., 2001. Plutonium: the legacy of Sellafield. In: Kudo, A. (Editor), Plutonium in the Environment. Radioactivity in the Environment. Elsevier, pp. 305-328.

Kershaw, P.J., McCubbin, D., Leonard, K.S., 1999b. Continuing contamination of north Atlantic and Arctic waters by Sellafield radionuclides. Science of The Total Environment 237-238, 119-132.

Kershaw, P.J., Woodhead, D.S., Lovett, M.B., Leonard, K.S., 1995b. Plutonium from European reprocessing operations - its behaviour in the marine environment. Applied Radiation and Isotopes 46, 1121-1134.

Kershaw, P.J., Woodhead, D.S., Malcolm, S.J., Allington, D.J., Lovett, M.B., 1990. A sediment history of Sellafield discharges. Journal of Environmental Radioactivity 12, 201-241.

Ketterer, M.E., Hafer, K.M., Mietelski, J.W., 2004. Resolving Chernobyl vs. global fallout contributions in soils from Poland using plutonium atom ratios measured by inductively coupled plasma mass spectrometry. Journal of Environmental Radioactivity 73, 183-201.

Ketterer, M.E., Szechenyi, S.C., 2008. Determination of plutonium and other transuranic elements by inductively coupled plasma mass spectrometry: A historical perspective and new frontiers in the environmental sciences. Spectrochimica Acta Part B: Atomic Spectroscopy 63, 719-737.

Kim, C.K., Kim, C.S., Chang, B.U., Choi, S.W., Chung, C.S., Hong, G.H., Hirose, K., Igarashi, Y., 2004. Plutonium isotopes in seas around the Korean Peninsula. Science of The Total Environment 318, 197-209.

Kim, C.S., Kim, C.K., Martin, P., Sansone, U., 2007. Determination of Pu isotope concentrations and isotope ratio by inductively coupled plasma mass spectrometry: a review of analytical methodology. Journal of Analytical Atomic Spectrometry 22, 827841.

Kishimoto, T., Sanada, T., Sato, K., Higuchi, H., 2002. Concentration of plutonium in squids collected from Japanese inshore measured by HR-ICP-MS, 1981-2000. Journal of Radioanalytical and Nuclear Chemistry 252, 395-398.

Koide, M., Bertine, K.K., Chow, T.J., Goldberg, E.D., 1985. The ${ }^{240} \mathrm{Pu} /{ }^{239} \mathrm{Pu}$ ratio, a potential geochronometer. Earth and Planetary Science Letters 72, 1-8.

Krey, P.W., 1967. Atmospheric burnup of a plutonium-238 generator. Science 158, 769-771. 
Krishnaswami, S., Benninger, L.K., Aller, R.C., Von Damm, K.L., 1980. Atmosphericallyderived radionuclides as tracers of sediment mixing and accumulation in near-shore marine and lake sediments: evidence from ${ }^{7} \mathrm{Be},{ }^{210} \mathrm{~Pb}$, and ${ }^{239,240} \mathrm{Pu}$. Earth and Planetary Science Letters 47, 307-318.

Landa, E.R., Reimnitz, E., Beals, D.M., Pochkowski, J.M., Winn, W.G., Rigor, I., 1998. Transport of ${ }^{137} \mathrm{Cs}$ and ${ }^{239,240} \mathrm{Pu}$ with ice-drafted debris in the Arctic Ocean. Arctic 51, 27-39.

Lansard, B., Charmasson, S., Gascó, C., Antón, M.P., Grenz, C., Arnaud, M., 2007. Spatial and temporal variations of plutonium isotopes $\left({ }^{238} \mathrm{Pu}\right.$ and $\left.{ }^{239,240} \mathrm{Pu}\right)$ in sediments off the Rhone River mouth (NW Mediterranean). Science of The Total Environment 376, 215-227.

Lansard, B., Grenz, C., Charmasson, S., Schaaff, E., Pinazo, C., 2006. Potential plutonium remobilisation linked to marine sediment resuspension: first estimates based on flume experiments. Journal of Sea Research 55, 74-85.

Lapicque, G., Livingston, H.D., Lambert, C.E., Bard, E., Labeyrie, L.D., 1987. Interpretation of 239,240Pu in Atlantic sediments with a non-steady state input model. Deep Sea Research Part A. Oceanographic Research Papers 34, 1841-1850.

Lee, S.-H., Povinec, P.P., Wyse, E., Pham, M.K., Hong, G.-H., Chung, C.-S., Kim, S.-H., Lee, H.-J., 2005. Distribution and inventories of ${ }^{90} \mathrm{Sr},{ }^{137} \mathrm{Cs},{ }^{241} \mathrm{Am}$ and $\mathrm{Pu}$ isotopes in sediments of the Northwest Pacific Ocean. Marine Geology 216, 249-263.

Lee, S.-Y., Huh, C.-A., Su, C.-C., You, C.-F., 2004. Sedimentation in the Southern Okinawa Trough: enhanced particle scavenging and teleconnection between the Equatorial Pacific and western Pacific margins. Deep Sea Research Part I: Oceanographic Research Papers 51, 1769-1780.

Leifer, R., Chan, N., 1997. The Environmental Measurements Laboratory's Stratospheric Radionuclide (RANDAB) and Trace Gas (TRACDAB) Databases. Environmental Measurements Laboratory, http://cdiac.esd.ornl.gov/epubs/db/db1019/db1019.html

León Vintró, L., Mitchell, P.I., Smith, K.J., Kershaw, P.J., Livingston, H.D., 2005. Transuranium nuclides in the world's oceans. In: Livingston, H.D. (Editor), Marine Radioactivity. Radioactivity in the Environment. Elsevier, pp. 79-108.

Leonard, K.S., McCubbin, D., Blowers, P., Taylor, B.R., 1999. Dissolved plutonium and americium in surface waters of the Irish Sea, 1973-1996. Journal of Environmental Radioactivity 44, 129-158.

Leonard, K.S., McCubbin, D., Lovett, M.B., 1995. Physico-chemical characterisation of radionuclides discharged from a nuclear establishment. Science of The Total Environment 175, 9-24.

Lind, O.C., Oughton, D.H., Salbu, B., Skipperud, L., Sickel, M.A., Brown, J.E., Fifield, L.K., Tims, S.G., 2006. Transport of low ${ }^{240} \mathrm{Pu} /{ }^{239} \mathrm{Pu}$ atom ratio plutonium-species in the $\mathrm{Ob}$ and Yenisey Rivers to the Kara Sea. Earth and Planetary Science Letters 251, 33-43.

Lind, O.C., Salbu, B., Janssens, K., Proost, K., Dahlgaard, H., 2005. Characterization of uranium and plutonium containing particles originating from the nuclear weapons accident in Thule, Greenland, 1968. Journal of Environmental Radioactivity 81, 21-32.

Lindahl, P., Roos, P., Holm, E., Dahlgaard, H., 2005. Studies of Np and Pu in the marine environment of Swedish-Danish waters and the North Atlantic Ocean. Journal of Environmental Radioactivity 82, 285-301. 
Livingston, H.D., Anderson, R.F., 1983. Large particle transport of plutonium and other fallout radionuclides to the deep ocean. Nature 303, 228-231.

Livingston, H.D., Povinec, P.P., 2000. Anthropogenic marine radioactivity. Ocean \& Coastal Management 43, 689-712.

Livingston, H.D., Povinec, P.P., 2002. A millennium perspective on the contribution of global fallout radionuclides to ocean science. Health Physics 82, 656-668.

Livingston, H.D., Povinec, P.P., Ito, T., Togawa, O., 2001. The behaviour of plutonium in the Pacific Ocean. In: Kudo, A. (Editor), Plutonium in the Environment. Radioactivity in The Environment. Elsevier, pp. 267-292.

Mark, J.C., 1993. Explosive properties of reactor-grade plutonium. Science \& Global Security 4, 111-128.

Masqué, P., Cochran, J.K., Hebbeln, D., Hirschberg, D.J., Dethleff, D., Winkler, A., 2003. The role of sea ice in the fate of contaminants in the Arctic Ocean: plutonium atom ratios in the Fram Strait. Environmental Science \& Technology 37, 4848-4854.

Masqué, P., Cochran, J.K., Hirschberg, D.J., Dethleff, D., Hebbeln, D., Winkler, A., Pfirman, S., 2007. Radionuclides in Arctic sea ice: tracers of sources, fates and ice transit time scales. Deep Sea Research Part I: Oceanographic Research Papers 54, 1289-1310.

McCubbin, D., Leonard, K.S., Emerson, H.S., 1999. The role of thermal and photochemical reactions upon the remobilisation of $\mathrm{Pu}$ from an Irish Sea sediment. Journal of Environmental Radioactivity 44, 253-273.

McDonald, P., Vives i Batlle, J., Bousher, A., Whittall, A., Chambers, N., 2001. The availability of plutonium and americium in Irish Sea sediments for re-dissolution. Science of The Total Environment 267, 109-123.

Meece, D.E., Benninger, L.K., 1993. The coprecipitation of $\mathrm{Pu}$ and other radionuclides with $\mathrm{CaCO}_{3}$. Geochimica et Cosmochimica Acta 57, 1447-1458.

Miralles, J., Radakovitch, O., Cochran, J.K., Véron, A., Masqué, P., 2004. Multitracer study of anthropogenic contamination records in the Camargue, Southern France. Science of The Total Environment 320, 63-72.

Mitchell, P.I., Downes, A.B., Vintró, L.L., McMahon, C.A., 2001. Studies of the speciation, colloidal association and remobilisation of plutonium in the marine environment. In: Kudo, A. (Editor), Plutonium in the Environment. Radioactivity in the Environment. Elsevier, pp. 175-200.

Mitchell, P.I., Vintró, L.L., Dahlgaard, H., Gascó, C., Sánchez-Cabeza, J.A., 1997. Perturbation in the ${ }^{240} \mathrm{Pu} /{ }^{239} \mathrm{Pu}$ global fallout ratio in local sediments following the nuclear accidents at Thule (Greenland) and Palomares (Spain). Science of The Total Environment 202, 147-153.

Mitchell, P.I., Vives i. Batlle, J., Downes, A.B., Condren, O.M., León Vintró, L., SánchezCabeza, J.A., 1995. Recent observations on the physico-chemical speciation of plutonium in the Irish Sea and the western Mediterranean. Applied Radiation and Isotopes 46, 1175-1190.

Moon, D.-S., Hong, G.-H., Kim, Y.I., Baskaran, M., Chung, C.S., Kim, S.H., Lee, H.-J., Lee, S.-H., Povinec, P.P., 2003. Accumulation of anthropogenic and natural radionuclides in bottom sediments of the Northwest Pacific Ocean. Deep Sea Research Part II: Topical Studies in Oceanography 50, 2649-2673. 
Morris, K., Butterworth, J.C., Livens, F.R., 2000. Evidence for the remobilization of Sellafield waste radionuclides in an intertidal salt marsh, West Cumbria, U.K. Estuarine, Coastal and Shelf Science 51, 613-625.

Mulsow, S., Coquery, M., Dovlete, C., Gastaud, J., Ikeuchi, Y., Pham, M.K., Povinec, P.P., 1999. Radionuclide concentrations in underground waters of Mururoa and Fangataufa Atolls. Science of The Total Environment 237-238, 287-300.

Muramatsu, Y., Hamilton, T., Uchida, S., Tagami, K., Yoshida, S., Robison, W., 2001. Measurement of ${ }^{240} \mathrm{Pu} /{ }^{239} \mathrm{Pu}$ isotopic ratios in soils from the Marshall Islands using ICP-MS. Science of The Total Environment 278, 151-159.

Muramatsu, Y., Ruhm, W., Yoshida, S., Tagami, K., Uchida, S., Wirth, E., 2000. Concentrations of ${ }^{239} \mathrm{Pu}$ and ${ }^{240} \mathrm{Pu}$ and their isotopic ratios determined by ICP-MS in soils collected from the Chernobyl 30-km zone. Environmental Science \& Technology 34, 2913-2917.

Nakanishi, T., Shiba, Y., Muramatsu, M., Haque, M., 1995. Estimation of mineral aerosol fluxes to the Pacific by using environmental plutonium as a tracer. In: Sakai, H. and Nozaki, Y. (Eds), Biogeochemical Processes and Ocean Flux in Western Pacific. Terra Scientific Publishing Company (TERRAPUB), Tokyo, Japan, pp. 15-30.

Nakano, M., Povinec, P.P., 2003. Modelling the distribution of plutonium in the Pacific Ocean. Journal of Environmental Radioactivity 69, 85-106.

Nelson, D.M., Carey, A.E., Bowen, V.T., 1984. Plutonium oxidation state distributions in the Pacific Ocean during 1980-1981. Earth and Planetary Science Letters 68, 422-430.

Nelson, D.M., Lovett, M.B., 1978. Oxidation state of plutonium in the Irish Sea. Nature 276, 599-601.

Nies, H., Harms, I.H., Karcher, M.J., Dethleff, D., Bahe, C., 1999. Anthropogenic radioactivity in the Arctic Ocean - review of the results from the joint German project. Science of The Total Environment 237-238, 181-191.

Noshkin, V.E., Wong, K.M., Eagle, R.J., Gatrousis, C., 1975. Transuranics and other radionuclides in Bikini Lagoon: concentration data retrieved from aged coral sections. Limnology and Oceanography 20, 729-742.

Noshkin, V.E., Wong, K.M., Jokela, T.A., Brunk, J.L., Eagle, R.J., 1987. Plutonium and americium behavior in coral atoll environments. In: Conner, T.P., Burt, C.W. and Duedall, I.A. (Eds), Oceanic Processes in Marine Pollution, pp. 159-174.

Noureddine, A., Benkrid, M., Maoui, R., Menacer, M., Boudjenoun, R., Kadi-hanifi, M., Lee, S.H., Povinec, P.P., 2008. Radionuclide tracing of water masses and processes in the water column and sediment in the Algerian Basin. Journal of Environmental Radioactivity 99, 1224-1232.

Nozaki, Y., Yamada, M., Nakanishi, T., Nagaya, Y., Nakamura, K., Shitashima, K., Tsubota, H., 1998. The distribution of radionuclides and some trace metals in the water columns of the Japan and Bonin trenches. Oceanologica Acta 21, 469-484.

Nyffeler, F., Cigna, A.A., Dahlgaard, H., Livingston, H.D., 1996. Radionuclides in the Atlantic Ocean: A survey. In: Guegueniat, P., Germain, P. and Metivier, H. (Eds), Radionuclides in the Oceans, Inputs and Inventories. Les Editions de Physique, Paris, France, pp. 1-28.

Oikawa, S., Yamamoto, M., 2007. Plutonium concentration and ${ }^{240} \mathrm{Pu} /{ }^{239} \mathrm{Pu}$ atomic ratio in 
liver of squid collected in the coastal sea areas of Japan. Journal of Environmental Radioactivity 93, 170-180.

Oktay, S.D., Santschi, P.H., Moran, J.E., Sharma, P., 2000. The ${ }^{129}$ Iodine bomb pulse recorded in Mississippi River Delta sediments: results from isotopes of $\mathrm{I}, \mathrm{Pu}, \mathrm{Cs}, \mathrm{Pb}$, and $\mathrm{C}$. Geochimica et Cosmochimica Acta 64, 989-996.

Olivier, S., Bajo, S., Fifield, L.K., Gaggeler, H.W., Papina, T., Santschi, P.H., Schotterer, U., Schwikowski, M., Wacker, L., 2004. Plutonium from global fallout recorded in an ice core from the Belukha Glacier, Siberian Altai. Environmental Science \& Technology $38,6507-6512$.

Olsen, C.R., Thein, M., Larsen, I.L., Lowry, P.D., Mulholland, P.J., Cutshall, N.H., Byrd, J.T., Windom, H.L., 1989. Plutonium, lead-210, and carbon isotopes in the Savannah estuary: riverborne versus marine sources. Environmental Science \& Technology 23, $1475-1481$.

Orlandini, K.A., Penrose, W.R., Harvey, B.R., Lovett, M.B., Findlay, M.W., 1990. Colloidal behavior of actinides in an oligotrophic lake. Environmental Science \& Technology 24, 706-712.

Osvath, I., Povinec, P.P., Baxter, M.S., 1999. Kara Sea radioactivity assessment. Science of The Total Environment 237-238, 167-179.

Oughton, D.H., Fifield, L.K., Day, J.P., Cresswell, R.C., Skipperud, L., Di Tada, M.L., Salbu, B., Strand, P., Drozcho, E., Mokrov, Y., 2000. Plutonium from Mayak: measurement of isotope ratios and activities using Accelerator Mass Spectrometry. Environmental Science \& Technology 34, 1938-1945.

Oughton, D.H., Skipperud, L., Fifield, L.K., Cresswell, R.G., Salbu, B., Day, P., 2004. Accelerator mass spectrometry measurement of ${ }^{240} \mathrm{Pu} /{ }^{239} \mathrm{Pu}$ isotope ratios in Novaya Zemlya and Kara Sea sediments. Applied Radiation and Isotopes 61, 249-253.

Oughton, D.H., Skipperud, L., Salbu, B., Fifield, L.K., Cresswell, R.C., Day, J.P., 1999. Determination of ${ }^{240} \mathrm{Pu} /{ }^{239} \mathrm{Pu}$ isotope ratios in Kara Sea and Novaya Zemlya sediments using Accelerator Mass Spectrometry, Symposium on Marine Pollution. IAEATECDOC-1094, Monaco, pp. 123-128.

Papucci, C., Charmasson, S., Delfanti, R., Gasco, C., Mitchell, P., Sanchez-Cabeza, J., 1996. Time evolution and levels of man-made radioactivity in the Mediterranean Sea. In: Guegueniat, P., Germain, P. and Metivier, H. (Eds), Radionuclides in the Oceans, Inputs and inventories. Les Editions de Physique, Paris, France, pp. 177-197.

Perkins, R.W., Thomas, C.W., 1980. Worldwide fallout. In: Hanson, W.C. (Editor), Transuranic Elements in the Environment. US DOE/TIC-22800. Office of Health and Environmental Research, pp. 53-82.

Pfirman, S.L., Eicken, H., Bauch, D., Weeks, W.F., 1995. The potential transport of pollutants by Arctic sea ice. Science of The Total Environment 159, 129-146.

Pöllänen, R., Ketterer, M.E., Lehto, S., Hokkanen, M., Ikäheimonen, T.K., Siiskonen, T., Moring, M., Rubio Montero, M.P., Martín Sánchez, A., 2006. Multi-technique characterization of a nuclear bomb particle from the Palomares accident. Journal of Environmental Radioactivity 90, 15-28.

Preller, R.H., Cheng, A., 1999. Modeling the transport of radioactive contaminants in the arctic. Marine Pollution Bulletin 38, 71-91. 
Purdy, C.B., Druffel, E.R.M., Hugh D, L., 1989. Anomalous levels of ${ }^{90} \mathrm{Sr}$ and ${ }^{239,240} \mathrm{Pu}$ in Florida corals: evidence of coastal processes. Geochimica et Cosmochimica Acta 53, 1401-1410.

Qiao, J., Hou, X., Miró, M., Roos, P., 2009. Determination of plutonium isotopes in waters and environmental solids: A review. Analytica Chimica Acta (In Press).

Roberts, K.A., Cochran, J.K., Barnes, C., 1997. ${ }^{210} \mathrm{~Pb}$ and ${ }^{239,240} \mathrm{Pu}$ in the Northeast Water Polynya, Greenland: particle dynamics and sediment mixing rates. Journal of Marine Systems 10, 401-413.

Robison, W.L., Noshkin, V.E., 1999. Radionuclide characterization and associated dose from long-lived radionuclides in close-in fallout delivered to the marine environment at Bikini and Enewetak Atolls. Science of The Total Environment 237-238, 311-327.

Ryan, T.P., 2002. Transuranic biokinetic parameters for marine invertebrates--a review. Environment International 28, 83-96.

Salbu, B., 2001. Actinides associated with particles. In: Kudo, A. (Editor), Plutonium in the Environment. Radioactivity in the Environment. Elsevier, pp. 121-138.

Salbu, B., Nikitin, A.I., Strand, P., Christensen, G.C., Chumichev, V.B., Lind, B., Fjelldal, H., Bergan, T.D.S., Rudjord, A.L., Sickel, M., Valetova, N.K., Føyn, L., 1997. Radioactive contamination from dumped nuclear waste in the Kara Sea -- results from the joint Russian-Norwegian expeditions in 1992-1994. Science of The Total Environment 202, 185-198.

Sanchez-Cabeza, J.-A., Merino, J., Masqué, P., Mitchell, P.I., Vintró, L.L., Schell, W.R., Cross, L., Calbet, A., 2003. Concentrations of plutonium and americium in plankton from the western Mediterranean Sea. The Science of The Total Environment 311, 233-245.

Sanchez, A.L., Gastaud, J., Holm, E., Roos, P., 1994. Distribution of plutonium and its oxidation states in Framvaren and Hellvik fjords, Norway. Journal of Environmental Radioactivity 22, 205-217.

Santschi, P.H., Li, Y.-H., Bell, J.J., Trier, R.M., Kawtaluk, K., 1980. Pu in coastal marine environments. Earth and Planetary Science Letters 51, 248-265.

Sato, Y., Yukimoto, S., Tsujino, H., Ishizaki, H., Noda, A., 2006. Response of North Pacific Ocean circulation in a Kuroshio-resolving ocean model to an Arctic Oscillation (AO)like change in northern hemisphere atmospheric circulation due to greenhouse-gas forcing. Journal of the Meteorological Society of Japan 84, 295-309.

Sholkovitz, E.R., 1983. The geochemistry of plutonium in fresh and marine water environments. Earth-Science Reviews 19, 95-161.

Skipperud, L., 2004. Plutonium in the Arctic Marine Environment - A Short Review. TheScientificWorldJOURNAL 4, 460-481.

Skipperud, L., Brown, J., Fifield, L.K., Oughton, D.H., Salbu, B., 2009. Association of plutonium with sediments from the $\mathrm{Ob}$ and Yenisey Rivers and Estuaries. Journal of Environmental Radioactivity 100, 290-300.

Skipperud, L., Oughton, D.H., Fifield, L.K., Lind, O.C., Tims, S., Brown, J., Sickel, M., 2004. Plutonium isotope ratios in the Yenisey and $\mathrm{Ob}$ estuaries. Applied Radiation and Isotopes 60, 589-593.

Smith, C.N., Clarke, S., McDonald, P., Goshawk, J.A., Jones, S.R., 2000a. Reconstructing historical radionuclide concentrations along the east coast of Ireland using a 
compartmental model. The Science of The Total Environment 254, 17-30.

Smith, J.N., Boudreau, B.P., Noshkin, V., 1986. Plutonium and ${ }^{210} \mathrm{~Pb}$ distributions in northeast Atlantic sediments: subsurface anomalies caused by non-local mixing. Earth and Planetary Science Letters 81, 15-28.

Smith, J.N., Ellis, K.M., Naes, K., Dahle, S., Matishov, D., 1995. Sedimentation and mixing rates of radionuclides in Barents Sea sediments off Novaya Zemlya. Deep Sea Research Part II: Topical Studies in Oceanography 42, 1471-1493.

Smith, J.N., Ellis, K.M., Polyak, L., Ivanov, G., Forman, S.L., Moran, S.B., 2000b. ${ }^{239,240}$ Pu transport into the Arctic Ocean from underwater nuclear tests in Chernaya Bay, Novaya Zemlya. Continental Shelf Research 20, 255-279.

Su, C.-C., Huh, C.-A., 2002. ${ }^{210} \mathrm{~Pb},{ }^{137} \mathrm{Cs}$ and ${ }^{239,240} \mathrm{Pu}$ in East China Sea sediments: sources, pathways and budgets of sediments and radionuclides. Marine Geology 183, 163-178.

Taylor, D.M., 2001. Environmental plutonium - creation of the universe to twenty-first century mankind. In: Kudo, A. (Editor), Plutonium in the Environment. Radioactivity in the Environment. Elsevier, pp. 1-14.

Thomas, A.J., 1997. Input of artificial radionuclides to the Gulf of Lions and tracing the Rhône influence in marine surface sediments. Deep Sea Research Part II: Topical Studies in Oceanography 44, 577-595.

Tsumune, D., Aoyama, M., Hirose, K., 2003. Numerical simulation of ${ }^{137} \mathrm{Cs}$ and ${ }^{239,240} \mathrm{Pu}$ concentrations by an ocean general circulation model. Journal of Environmental Radioactivity 69, 61-84.

UNSCEAR, 2000a. Sources and Effects of Ionizing Radiation, Volume I: Sources, United Nations Scientific Committee on the Effects of Atomic Radiation, Report to the General Assembly, with Scientific Annexes, United Nations, New York, 649 pp.

UNSCEAR, 2000b. Sources and Effects of Ionizing Radiation, Volume II: Effects, United Nations Scientific Committee on the Effects of Atomic Radiation, Report to the General Assembly, with Scientific Annexes, United Nations, New York, 580 pp.

Wang, Z.-1., Yamada, M., 2005. Plutonium activities and ${ }^{240} \mathrm{Pu} /{ }^{239} \mathrm{Pu}$ atom ratios in sediment cores from the east China sea and Okinawa Trough: sources and inventories. Earth and Planetary Science Letters 233, 441-453.

Warneke, T., Croudace, I.W., Warwick, P.E., Taylor, R.N., 2002. A new ground-level fallout record of uranium and plutonium isotopes for northern temperate latitudes. Earth and Planetary Science Letters 203, 1047-1057.

Wendt, K., Blaum, K., Bushaw, B.A., Grüning, C., Horn, R., Huber, G., Kratz, J.V., Kunz, P., Müller, P., Nörtershäuser, W., Nunnemann, M., Passler, G., Schmitt, A., Trautmann, N., Waldek, A., 1999. Recent developments in and applications of resonance ionization mass spectrometry. Fresenius' Journal of Analytical Chemistry 364, 471-477.

Wolf, S.F., Bates, J.K., Buck, E.C., Dietz, N.L., Fortner, J.A., Brown, N.R., 1997. Physical and chemical characterization of actinides in soil from Johnston Atoll. Environmental Science \& Technology 31, 467-471.

Yamada, M., Aono, T., 2002. Large particle flux of ${ }^{239+240} \mathrm{Pu}$ on the continental margin of the East China Sea. Science of The Total Environment 287, 97-105.

Yamada, M., Aono, T., 2006. ${ }^{238} \mathrm{U}$, Th isotopes, ${ }^{210} \mathrm{~Pb}$ and ${ }^{239+240} \mathrm{Pu}$ in settling particles on the continental margin of the East China Sea: fluxes and particle transport processes. 
Marine Geology 227, 1-12.

Yamada, M., Zheng, J., 2008. Determination of ${ }^{240} \mathrm{Pu} /{ }^{239} \mathrm{Pu}$ atom ratio in coastal surface seawaters from the western North Pacific Ocean and Japan Sea. Applied Radiation and Isotopes 66, 103-107.

Yamada, M., Zheng, J., Wang, Z.-L., 2006. ${ }^{137} \mathrm{Cs},{ }^{239+240} \mathrm{Pu}$ and ${ }^{240} \mathrm{Pu} /{ }^{239} \mathrm{Pu}$ atom ratios in the surface waters of the western North Pacific Ocean, eastern Indian Ocean and their adjacent seas. Science of The Total Environment 366, 242-252.

Yamada, M., Zheng, J., Wang, Z.-L., 2007. ${ }^{240} \mathrm{Pu} /{ }^{239} \mathrm{Pu}$ atom ratios in seawater from Sagami Bay, western Northwest Pacific Ocean: sources and scavenging. Journal of Environmental Radioactivity 98, 274-284.

Yamamoto, M., Hoshi, M., Takada, J., Sakaguchi, A., Apsalikov, K., Gusev, B., 2004. Distributions of Pu isotopes and ${ }^{137} \mathrm{Cs}$ in soil from Semipalatinsk Nuclear Test Site detonations throughout southern districts. Journal of Radioanalytical and Nuclear Chemistry 261, 19-36.

Yamana, H., Yamamoto, T., Moriyama, H., 2001. Isotopic ratio of Pu released from fuel cycle facilities - importance of radiochemically pure ${ }^{236} \mathrm{Pu}$ as a tracer. In: Kudo, A. (Editor), Plutonium in the Environment. Radioactivity in the Envionment. Elsevier, pp. 31-46.

Zheng, J., Yamada, M., 2004. Sediment core record of global fallout and Bikini close-in fallout Pu in Sagami Bay, western Northwest Pacific margin. Environmental Science \& Technology 38, 3498-3504.

Zheng, J., Yamada, M., 2005a. Investigating Pu and U isotopic compositions in sediments: a case study in Lake Obuchi, Rokkasho Village, Japan using sector-field ICP-MS and ICP-QMS. Journal of Environmental Monitoring 7, 792-797.

Zheng, J., Yamada, M., 2005b. Vertical distributions of ${ }^{239+240} \mathrm{Pu}$ activities and ${ }^{240} \mathrm{Pu} /{ }^{239} \mathrm{Pu}$ atom ratios in sediment cores: implications for the sources of $\mathrm{Pu}$ in the Japan Sea. Science of The Total Environment 340, 199-211.

Zheng, J., Yamada, M., 2006a. Determination of Pu isotopes in sediment cores in the Sea of Okhotsk and the NW Pacific by sector field ICP-MS. Journal of Radioanalytical and Nuclear Chemistry 267, 73-83.

Zheng, J., Yamada, M., 2006b. Plutonium Isotopes in Settling Particles: Transport and Scavenging of $\mathrm{Pu}$ in the Western Northwest Pacific. Environmental Science \& Technology 40, 4103-4108. 
Table 1. Principal sources in the marine environment and their specific Pu isotopic composition expressed as ${ }^{240} \mathrm{Pu} /{ }^{239} \mathrm{Pu}$ atom and ${ }^{238} \mathrm{Pu} /{ }^{239+240} \mathrm{Pu}$ activity ratios. Uncertainties are expressed as $\pm 2 \mathrm{SD}$ (95\% confidence level).

\begin{tabular}{|c|c|c|c|c|}
\hline Main sources & $\begin{array}{l}{ }^{240} \mathrm{Pu} /{ }^{239} \mathrm{Pu} \\
\text { atom ratio }\end{array}$ & $\begin{array}{l}{ }^{238} \mathrm{Pu} /{ }^{239+240} \mathrm{Pu} \\
\text { activity ratio }\end{array}$ & References & $V$ \\
\hline
\end{tabular}

Atmospheric weapons testing, 1945-1980

$\begin{array}{lll}\text { Integrated global fallout } \quad 0.178 & 0.023 \quad 0.019 \pm 0.006\end{array}$

$\underline{\text { Specific test sites }}$

Marshall Islands

Johnston Atoll

French Polynesia

$0.29 \pm 0.04$

$\sim 0.06$

$0.02-0.05$

$0.1-0.4$

$0.032 \pm 0.006$

$0.038 \pm 0.016$

Semipalatinsk

$0.0320 \pm 0.0024 \quad 0.023 \pm 0.009$

Chernaya Bay, underwater nuclear tests

Releases from the nuclear industry

Sellafield (up to 1996)

$0.06-0.25$

$0.03-0.4$

La Hague effluent, 1996

Russian river discharges from nuclear reprocessing plants at Krasnoyarsk, Mayak, Tomsk

\section{$0.34 \pm 0.06$}

$0.05-0.30$

\section{Accidental releases}

Chernobyl accident, 1986

$$
0.38 \pm 0.07 \quad 0.42 \pm 0.04
$$

Thule accident, 1968

$\begin{array}{ll}0.055 \pm 0.008 & 0.0161 \pm \\ 0.063 \pm 0.006 & 0.0010 \\ & 0.015 \pm 0.004\end{array}$

Palomares accident, 1966

\section{SNAP-9A, 1964}

N Hemisphere

S Hemisphere

\section{Dumping sites}

\section{Kara Sea}

Sunken submarine reactors

$$
\sim 0.44
$$

(Perkins and Thomas, 1980;

Kelley et al., 1999)

(Muramatsu et al., 2001)

(Wolf et al., 1997)

(IAEA, 1998b; Chiappini et al., 1999; Mulsow et al., 1999; Danesi et al., 2002; Hrnecek et al., 2005) (Hicks and Barr, 1984)

(Beasley et al., 1998; Yamamoto et al., 2004)

(Smith et al., 1995; Smith et al., 2000b)

(Kershaw et al., 1990; Kershaw et al., 1995a; Morris et al., 2000)

(Oughton et al., 1999)

(Oughton et al., 2000; Skipperud et al., 2004; Børretzen et al., 2005; Lind et al., 2006; GauthierLafaye et al., 2008; Skipperud et al., 2009)

(Boulyga et al., 1997; Wendt et al., 1999; Muramatsu et al., 2000; Boulyga and Becker, 2002) (Lind et al., 2005; Eriksson et al., 2008)

(Chamizo et al., 2006; Pöllänen et al., 2006; Jiménez-Ramos et al., 2007)

$0.010 \pm 0.005 \quad$ (Perkins and Thomas, 1980)

$0.12 \pm 0.07$

(IAEA, 1998a)

(Oughton et al., 2004)

\footnotetext{
* Decay corrected to the year 2000.
} 
Table 2. Estimated $\mathrm{Pu}$ isotope inventory $(\mathrm{PBq})$ in the world's oceans originating from atmospheric nuclear weapons tests, 1945 - 1980 (Aarkrog, 2003; Hamilton, 2005).

\begin{tabular}{|c|c|c|c|c|c|}
\hline & ${ }^{238} \mathrm{Pu}^{\mathrm{a}}$ & ${ }^{239} \mathrm{Pu}$ & ${ }^{240} \mathrm{Pu}$ & ${ }^{241} \mathrm{Pu}^{\mathrm{a}}$ & ${ }^{242} \mathrm{Pu}$ \\
\hline Arctic Ocean & 0.002 & 0.05 & 0.04 & 0.17 & 0.00001 \\
\hline Atlantic Ocean & 0.05 & 1.38 & 0.89 & 4.24 & 0.0003 \\
\hline North Atlantic & 0.04 & 1.1 & 0.7 & 3.4 & 0.00023 \\
\hline South Atlantic & 0.01 & 0.3 & 0.2 & 0.9 & 0.00006 \\
\hline Indian Ocean & 0.02 & 0.56 & 0.36 & 1.73 & 0.0002 \\
\hline Pacific Ocean $^{\text {b }}$ & 0.35 & 4.47 & 3.98 & 23.89 & 0.003 \\
\hline North Pacific & 0.17 & 2.7 & 2.3 & 13.5 & 0.0015 \\
\hline South Pacific & 0.07 & 1.8 & 1.7 & 10.4 & 0.0015 \\
\hline Southern Ocean & 0.005 & 0.07 & 0.05 & 0.24 & 0.00006 \\
\hline All Oceans & 0.4 & 6.5 & 5.4 & 30 & 0.004 \\
\hline
\end{tabular}




\section{Figure captions}

Figure 1. Total annual yield energies (Mt per year) and annual fallout debris deposition (from

${ }^{90} \mathrm{Sr}$ deposition, $\mathrm{PBq}$ per year) in the northern and southern hemispheres produced from atmospheric nuclear tests, 1945-1980 (UNSCEAR, 2000a).

Figure 2. ${ }^{239+240} \mathrm{Pu}$ discharges from the Sellafield reprocessing plant, 1952 - 2007 (Gray et al., 1995; BNFL, 2002; 2007) and ${ }^{240} \mathrm{Pu} /{ }^{239} \mathrm{Pu}$ atom ratios from dated sediment cores collected in the vicinity of the Sellafield plant (Kershaw et al., 1995a; Morris et al., 2000).

Figure 3. Biogochemical cycle of $\mathrm{Pu}$ in the marine environment. Adapted from Choppin and Morgenstern (2001).

Figure 4. ${ }^{239+240} \mathrm{Pu}$ depth profiles in seawater from various stations in the North Pacific Ocean (Bowen et al., 1980; Nelson et al., 1984; Nozaki et al., 1998; Yamada et al., 2007).

Figure 5. Time series of ${ }^{240} \mathrm{Pu} /{ }^{239} \mathrm{Pu}$ atom ratio in three sites in the Pacific Ocean (Buesseler, 1997; Lee et al., 2004; Zheng and Yamada, 2004). The sedimentation rate for the Sagami Bay site was estimated from the global fallout ${ }^{239+240} \mathrm{Pu}$ peak. 


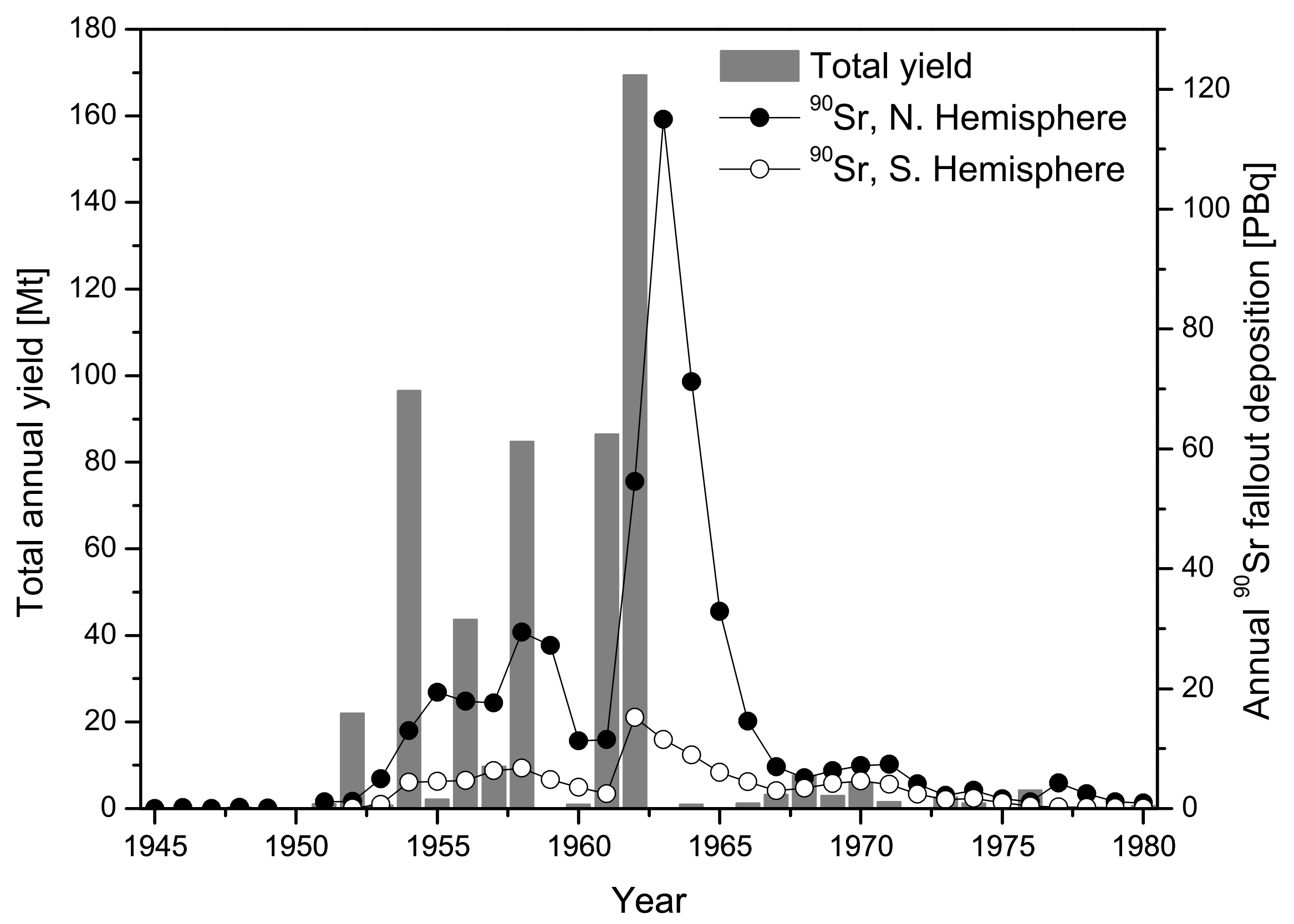




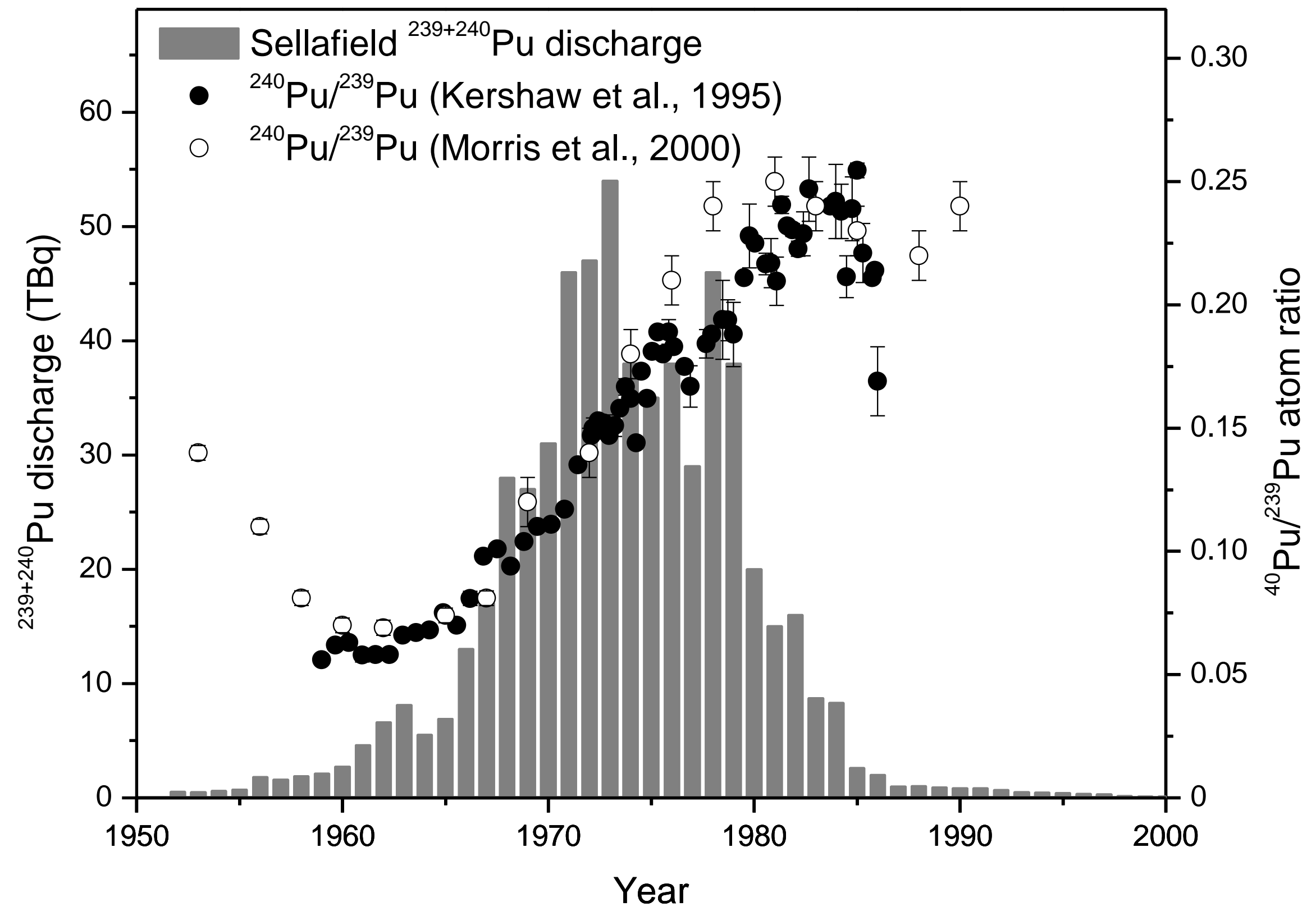




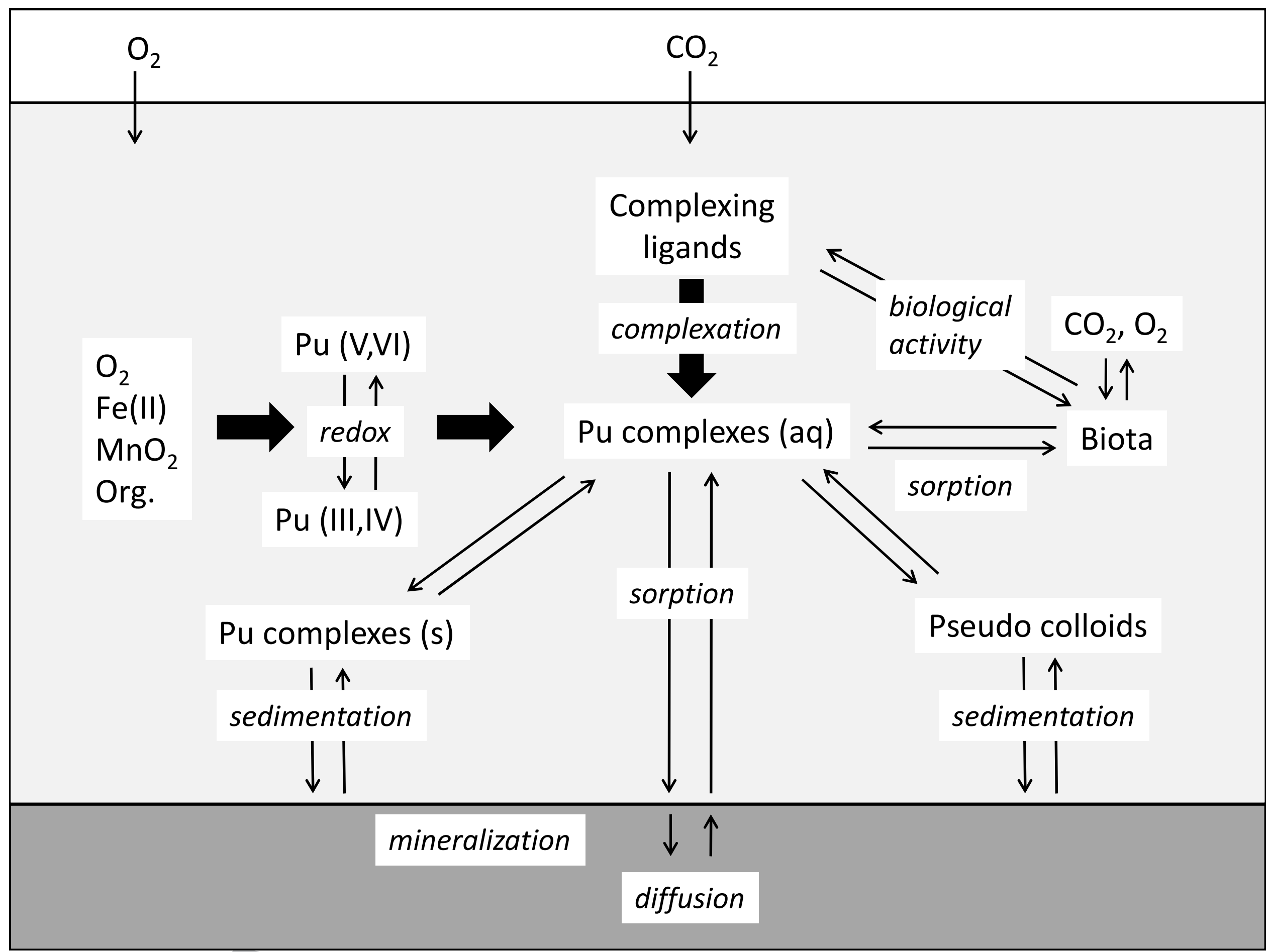




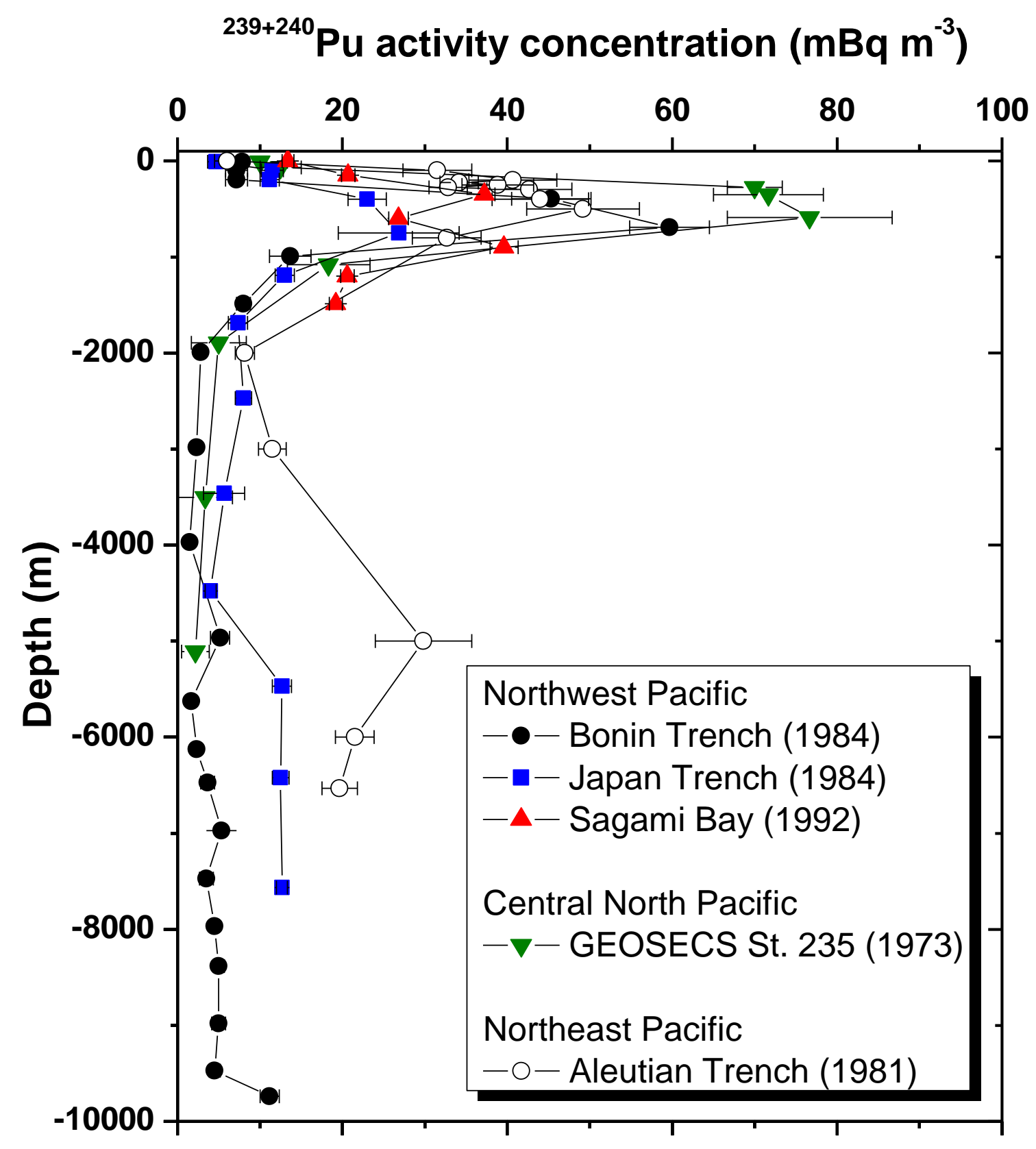




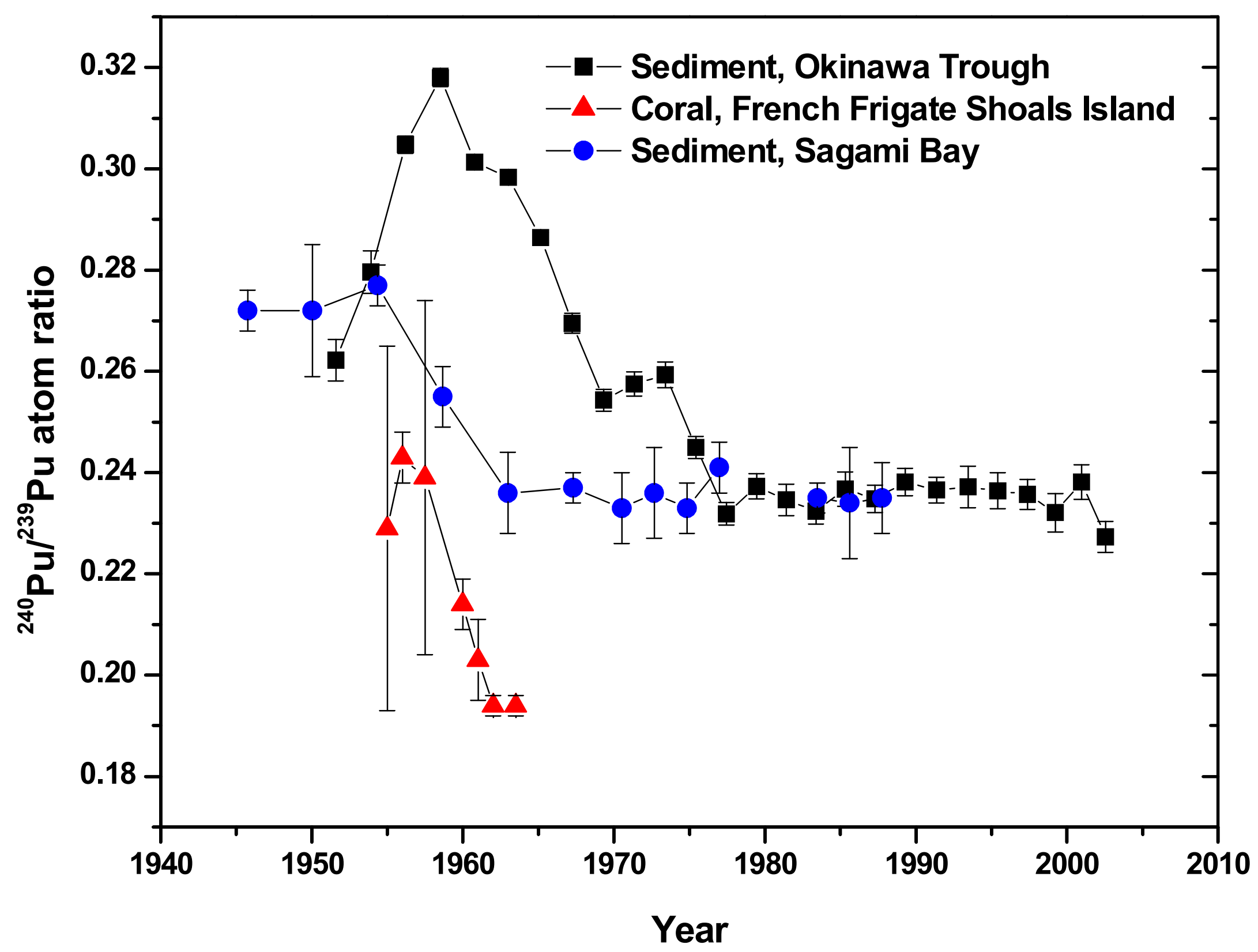

